University of Nebraska - Lincoln

DigitalCommons@University of Nebraska - Lincoln

2012

\title{
Diatom Evidence for the Onset of Pliocene Cooling from AND-1B, McMurdo Sound, Antarctica
}

Christina R. Riesselman

Stanford University, criesselman@gmail.com

Robert B. Dunbar

Stanford University

Follow this and additional works at: http://digitalcommons.unl.edu/andrillrespub

Part of the Oceanography Commons, and the Paleobiology Commons

Riesselman, Christina R. and Dunbar, Robert B., "Diatom Evidence for the Onset of Pliocene Cooling from AND-1B, McMurdo Sound, Antarctica" (2012). ANDRILL Research and Publications. 62.

http://digitalcommons.unl.edu/andrillrespub/62

This Article is brought to you for free and open access by the Antarctic Drilling Program at DigitalCommons@University of Nebraska - Lincoln. It has been accepted for inclusion in ANDRILL Research and Publications by an authorized administrator of DigitalCommons@University of Nebraska Lincoln. 
Published in Palaeogeography, Palaeoclimatology, Palaeoecology 369 (2013), 136-153;

doi: 10.1016/j.palaeo.2012.10.014

Copyright (C) 2012 Elsevier B.V. Used by permission.

Submitted January 1, 2012; revised September 11, 2012, accepted October 15, 2012;

published online October 23, 2012

\title{
Diatom evidence for the onset of Pliocene cooling from AND-1B, McMurdo Sound, Antarctica
}

\author{
Christina R. Riesselman, ${ }^{1}$ Robert B. Dunbar ${ }^{2}$
}

1. Department of Geological and Environmental Sciences, Stanford University, Stanford, CA 94305-2115, United States

2. Department of Environmental Earth System Science, Stanford University, Stanford, CA 94305-2115, United States

Corresponding author - Christina R. Riesselman, Eastern Geology and Paleoclimate Science Center, U.S. Geological Survey, 926A National Center, Reston, VA 20192, United States. Tel.: +1 703648 6028; fax: +1 703648 6953. email criesselman@gmail.com (C.R. Riesselman).

\begin{abstract}
The late Pliocene, $\sim 3.3-3.0 \mathrm{Ma}$, is the most recent interval of sustained global warmth in the geologic past. This window is the focus of climate reconstruction efforts by the U.S. Geological Survey's Pliocene Research, Interpretation, and Synoptic Mapping (PRISM) Data/Model Cooperative, and may provide a useful climate analog for the coming century. Reconstructions of past surface ocean conditions proximal to the Antarctic continent are essential to understanding the sensitivity of the cryosphere to this key interval in Earth's climate evolution. An exceptional marine sediment core collected from the southwestern Ross Sea (78 $\mathrm{S}$ ), Antarctica, during ANDRILL's McMurdo Ice Shelf Project preserves evidence of dramatic fluctuations between grounded ice and productive, open ocean conditions during the late Pliocene, reflecting orbitally-paced glacial/interglacial cycling. In this near-shore record, diatom-rich sediments are recovered from interglacial intervals; two of these diatomites, from $\sim 3.2 \mathrm{Ma}$ and $3.03 \mathrm{Ma}$, are within the PRISM chronologic window. The diatom assemblages identified in PRISM-age late Pliocene diatom-rich sediments are distinct from those in mid-Pliocene and later Pliocene/Pleistocene intervals recovered from AND-1B, and comprise both extant taxa with well-constrained ecological preferences and a diverse extinct flora, some members of which are previously undescribed from Antarctic sediments. Both units are dominated by Chaetoceros resting spores, an indicator of high productivity and stratification that is present at much lower abundance in materials both older and younger than the PRISM-age sediments. Newly described species of the genus Fragilariopsis, which first appear in the AND-1B record at 3.2 Ma, are the most abundant extinct members of the PRISMage assemblages. Other extant species with established environmental affinities, such as Fragilariopsis sublinearis, F. curta, Stellarima microtrias, and Thalassiothrix antarctica, are present at lower abundances. Environmental inferences drawn from extant diatom assemblages are in good agreement with those from Chaetoceros resting spores and the Fragilariopsis radiation. All three lines of evidence indicate the onset of late Pliocene cooling in the Ross Sea near-shore environment at 3.2 Ma, with intensification and possible regional persistence of summer sea ice by 3.03 Ma. An important implication of this research is the indication that the Ross Ice Shelf fluctuated dramatically on orbital timescales at a time when nearshore Antarctic conditions were only modestly warmer than present.
\end{abstract}

Keywords: Pliocene, Diatoms, Antarctica, Ross Sea Antarctic Geological Drilling (ANDRILL)

\section{Introduction}

\subsection{Background}

The Antarctic continent plays a fundamental role in the modulation of global and regional circulation, climate, and sea level. In its present glaciated state, Antarctica amplifies the Southern Hemisphere meridional thermal gradient, enhancing atmospheric circulation (Lemke et al., 1980; Flohn, 1984; Raphael, 2003) and generating strong, cold winds that contribute to the formation of Antarctic bottom water by cooling surface waters and sustaining sea ice production (Gordon, 2009). Wind intensification may also contribute to an increase in the fertility of Southern Ocean surface waters, by increasing surface circulation and upwelling at frontal zones, and by transporting iron-rich dust from the continents (Martin, 1990; Martínez-Garcia et al., 2011). On geological timescales, polar ice sheets strongly influence regional and global sea level, planetary albedo, continental weathering rates, and ocean and atmospheric chemistry. Each of these factors has the potential to trigger largescale geochemical or physical climate system feedbacks (e.g., Matthews and Poore, 1980; Barron, 1985; Gibbs and Kump, 1994; Zachos et al., 1996, 2001b). Because the Antarctic system exerts such a dramatic influence on the planet as a whole, understanding how the Antarctic cryosphere responded to warmer climates of the past will provide important constraints in forecasting future climate behavior. 


\subsection{Interval of focus}

Existing paleoclimate reconstructions identify the middle portion of the late Pliocene, $\sim 3 \mathrm{Ma}$, as a promising analog in the recent geologic past for our anticipated planetary future (Dowsett et al., 2012). (This interval is hereafter referred to as the "late Pliocene" for simplicity.) When forecasting global temperatures over the coming century, even the most conservative climate models predict a range of global warming that was last encountered during the late Pliocene (Dowsett, 2007; IPCC, 2007). In addition, this interval is geologically recent enough that continental positions and land-sea configurations were similar to the present. Furthermore, the Northern Hemisphere supported only ephemeral ice growth until the end of the late Pliocene warm interval $(\sim 2.7 \mathrm{Ma})$, when the first extensive northern ice sheets shifted the planet from a unipolar glacial state into its current state of bipolar glaciation (Gupta and Thomas, 2003; Lisiecki and Raymo, 2005; Raymo et al., 2006). The current weakening of the Northern Hemisphere cryosphere, as expressed through declining perennial sea ice coverage and rapid polar warming (Serreze et al., 2007; Comiso et al., 2008; Stroeve et al., 2012), suggests a planetary future for which the Pliocene is an increasingly apt analog. When viewed through the lens of the past, it is apparent that predictions of our immediate future depend on our understanding of this period of Pliocene warmth (Jansen et al., 2007). Yet there are still critical components of the earth system in the late Pliocene, notably the sensitivity of the Antarctic cryosphere, that remain poorly constrained.

Over the past two decades, researchers within the USGS Pliocene Research, Interpretation, and Synoptic Mapping (PRISM) Data/Model Cooperative have developed an extensive suite of regional and global paleoclimate and paleoecological reconstructions, as well as model simulations for the late Pliocene, from 3.264 to 3.025 Ma. Designed to constrain global conditions during this warmer-than-present analog interval, PRISM now provides the most comprehensive pre-Quaternary global climate synthesis available (e.g., Dowsett et al., 1999; Haywood and Valdes, 2004 and references therein; Dowsett, 2007; Dowsett et al., 2009; Haywood et al., 2009a, 2009b). Within this synthesis, insights on Antarctic participation in the Pliocene climate system have largely been filtered through its fingerprint on the Southern Ocean. Late Pliocene diatom-based reconstructions of the Antarctic Polar Front (APF) document a southward migration of up to $6^{\circ}$ latitude, with summer sea surface temperatures (SSTs) between $2^{\circ}$ and $3{ }^{\circ} \mathrm{C}$ warmer than present at latitudes of $55-65^{\circ} \mathrm{S}$ and a contracted winter sea ice edge that roughly corresponds to the modern summer ice edge (Barron, 1996a,b; Dowsett et al., 1996). Summer sea ice, though not entirely absent, is inferred to have been greatly reduced in extent (Barron, 1996a), a conclusion supported by Eucampia antarc- tica-based reconstructions from Prydz Bay (Whitehead et al., 2005).

The PRISM diatom reconstructions provide conclusive evidence of a warmer Southern Ocean during the late Pliocene. However, these records are largely developed from Deep Sea Drilling Project (DSDP) and Ocean Drilling Program (ODP) cores collected from open ocean sites. These sites are removed from the erosive influence of Antarctic continental ice and thus have the benefit of relatively continuous sediment accumulation, yet this distance also insulates them from the direct influence of the ice sheets and ice shelves whose responsiveness to global change through the Neogene remains a matter of debate (e.g., Miller and Mabin, 1998; Haywood et al., 2008).

A series of land- and ice-based drilling programs in the coastal McMurdo Sound region (Brady, 1981; Winter and Harwood, 1997; Bohaty et al., 1998; Winter et al., 2012a) and outcrop-based investigations of inland glaciomarine sedimentary sequences (Harwood et al., 2000) have sought more direct evidence of the nearshore biotic response to Neogene fluctuations of the Antarctic cryosphere. Of the diverse sections documented in these efforts, only the CIROS-2 drillcore from McMurdo Sound (Winter and Harwood, 1997; Winter et al., 2012a) and possibly the Bardin Bluffs Formation of the Pagodroma Group in the Amery Oasis (Whitehead et al., 2004) overlap with the late Pliocene PRISM interval of focus. However, these proximal records are discontinuous due to sediment removal by the very glacial fluctuations we seek to reconstruct, and paleoenvironmental interpretations have been drawn from diatom-bearing mudstone, sandstone, and diamict, in contrast to the rich diatomites preserved in distal diatom-ooze belt settings (Burckle, 1984; Burckle and Cirilli, 1987; Barron, 1996b).

\section{PRISM diatomites in southern McMurdo Sound}

Reconstructions of past surface ocean conditions proximal to the Antarctic continent are essential to understanding the sensitivity of the cryosphere to changing climate. In cryosphere models forced by orbital geometry and declining atmospheric $\mathrm{CO} 2$ levels, East Antarctic ice grounded at sea level is a prerequisite for the development of a sea ice belt around the continent (DeConto et al., 2007). Furthermore, models identify the McMurdo Sound region as an initial locus of sea ice production under these conditions (DeConto et al., 2007; Pollard and DeConto, 2009).

\subsection{ANDRILL core AND-1B}

The marine sediment core AND-1B collected by the Antarctic Geological Drilling (ANDRILL) Program from beneath the McMurdo Ice Shelf provides the longest, most complete record to date of Neogene climatic evo- 


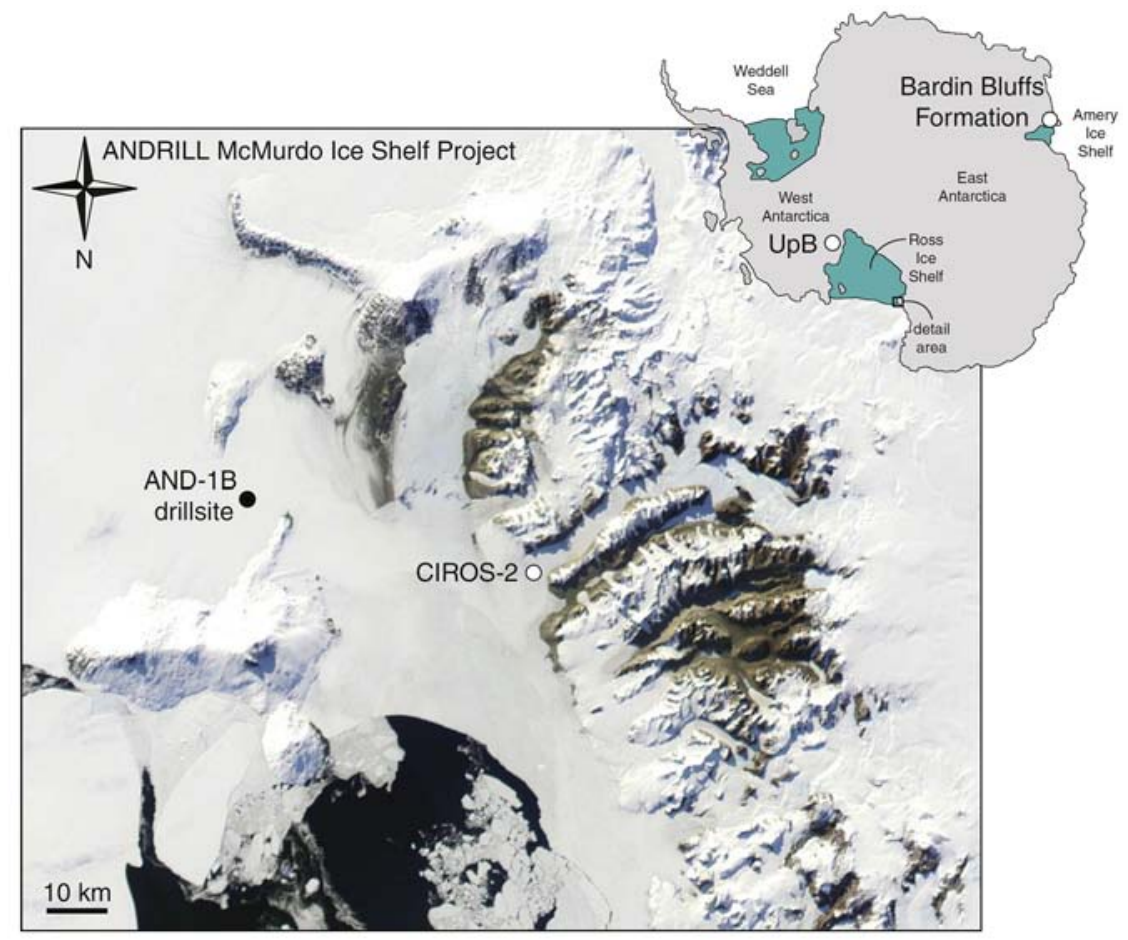

Figure 1. Map of the southern Ross Sea and McMurdo Sound region. The filled circle indicates the location of the ANDRILL McMurdo Ice Shelf (MIS) AND-1B drillsite and open circles indicate the locations of other sites discussed in the text.

lution proximal to the Antarctic continent and preserves evidence of the transition from a coastal temperate glacial regime to modern cold polar conditions (Naish et al., 2007b). Diatom-rich lithologic units alternate with glacial sediments in the upper six hundred meters of AND-1B, providing direct evidence of orbitallyinduced cycles in icesheet extent and glacial proximity throughout the Pliocene and early Pleistocene (Naish et al., 2007b, 2009). Each diatomite within this oscillating record has distinctive assemblage characteristics (Scherer et al., 2007); although one unit appears to preserve a continuous interval of open ocean conditions from 3.6 to $3.4 \mathrm{Ma}$, most are interpreted to preserve the interglacial interval of a single $40 \mathrm{kyr}$ glacial/interglacial cycle (Naish et al., 2009; Winter et al., 2010; Konfirst et al., 2011; McKay et al., 2012). The loss of additional interglacial intervals by subsequent glacial advance is also identified by the presence of glacial surfaces of erosion (GSEs) that truncate some diamictites (Krissek et al., 2007; McKay et al., 2009). In all, the AND-1B core preserves evidence of nearly 60 oscillations of ice advance and retreat (McKay et al., 2009); thirty-eight of these cycles in the upper $600 \mathrm{~m}$ of the core record oscillations during the past $5 \mathrm{Myr}$. In sequence, these units offer an unparalleled perspective on the changing character of the interglacial environment in the Ross Embayment, spanning the transition from the warm intervals of the Pliocene to modern cold polar conditions.

The 1285-m-long AND-1B marine sediment core was collected with $98 \%$ recovery from $77.89^{\circ} \mathrm{S}, 167.09^{\circ} \mathrm{E}$
(Fig. 1). The drillsite is located beneath a floating portion of the McMurdo Ice Shelf (the northwestern portion of the Ross Ice Shelf) (Falconer et al., 2007) on the western margin of the Victoria Land Basin within the Terror Rift (Naish et al., 2007a; McKay et al., 2009). Ice shelf thickness at the AND-1B drillsite was $\sim 82 \mathrm{~m}$ during coring, and the core was collected from a water depth of $\sim 917$ $\mathrm{m}$, reflecting the local influence of volcanic load-induced subsidence (Falconer et al., 2007; Naish et al., 2007a). Within this slowly subsiding depocenter, the AND-1B record accumulated in the accommodation space created within a progressively deepening flexural moat basin (Naish et al., 2007a). This unusual setting preserved an extensive nearshore marine sediment record, despite migration of the Ross Ice Shelf grounding line during Pliocene and Pleistocene glacial advances.

\subsection{PRISM-age diatom units in AND-1B}

Diatom assemblages are an excellent tool for reconstructing sea ice and a variety of other Antarctic surface ocean characteristics over geologic timescales (Armand, 2000; Crosta et al., 2008; Armand and Leventer, 2010; Röthlisberger et al., 2010). Diatoms are the dominant primary producer preserved in sediments south of the Polar Frontal Zone (PFZ), where conditions do not favor preservation of carbonate-producing organisms. Environmental selection is the primary determinant of diatom community structure (Cermeño and Falkowski, 2009). Individual species are sensitive to temperature, sea ice concentration and duration, water column strati- 


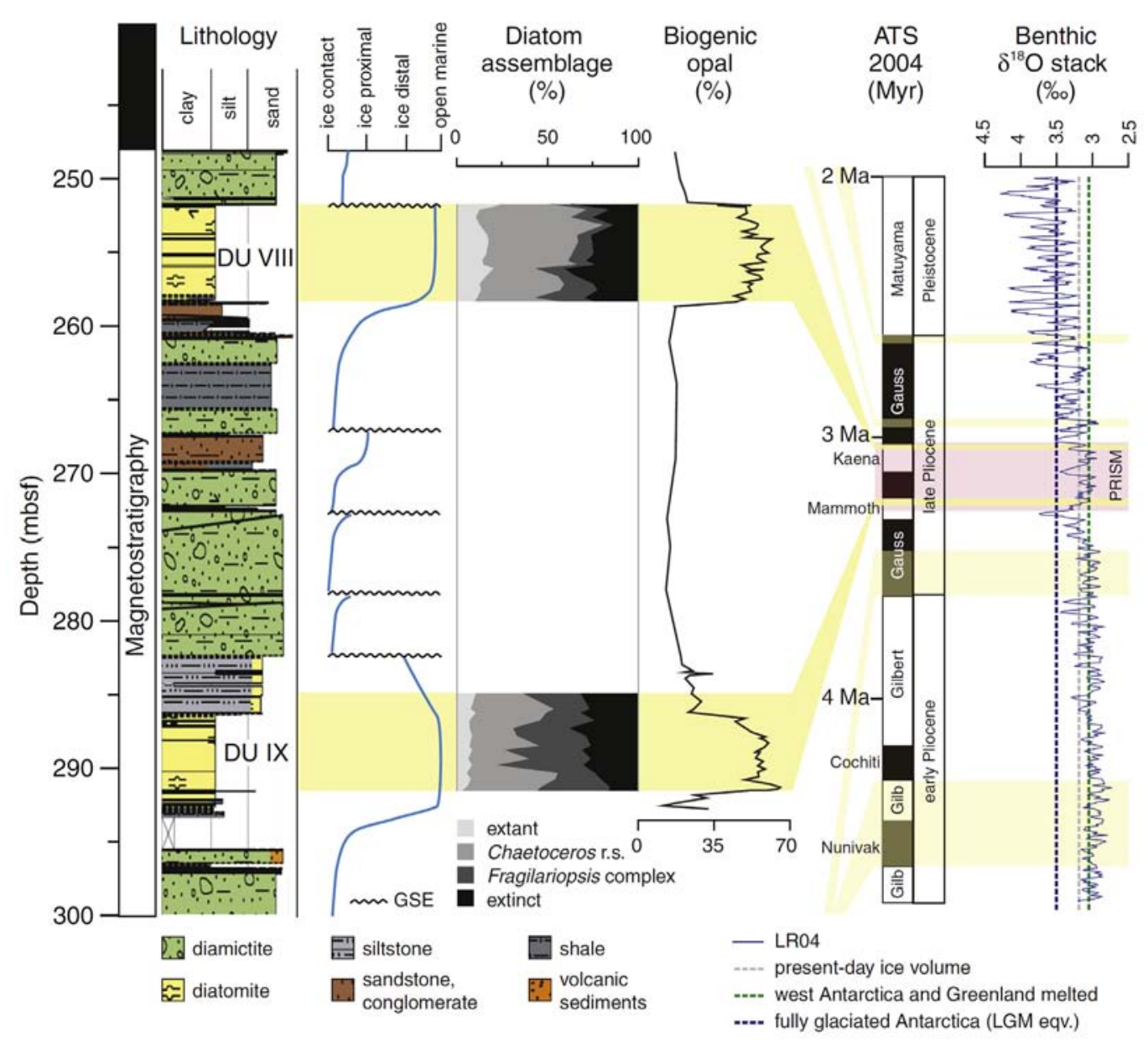

Figure 2. Summary of the AND-1B core from 248 to 300mbsf.Magnetostratigraphy after Wilson et al. (2007). Lithostratigraphy after Krissek et al. (2007). Glacial proximity curve after Naish et al. (2009); grounding line advances for five glacial/interglacial cycles are identified by glacial surfaces of erosion (GSEs). Diatom assemblage panel distinguishes relative abundance of Chaetoceros resting spores (r.s.) and other extant taxa from newly described Fragilariopsis species and other extinct taxa in DU IX and VIII, the two interglacial intervals preserved as diatomites with $>50 \%$ biogenic silica by weight. Bold yellow fields mark the position of DU IX and DU VIII within the astronomically tuned timescale of (ATS) of Gradstein et al. (2005) and associated cycles on the benthic $\delta 18 \mathrm{O}$ stack of Lisiecki and Raymo (2005). The Pliocene-Pleistocene boundary is placed in accordance with the 2009 Geologic Time Scale of the International Commission on Stratigraphy. Pink window across ATS and $\delta 180$ stack highlights the PRISM interval of focus (Dowsett et al., 2009); pale yellow fields mark the ages of other interglacial diatomite intervals recovered in AND-1B (Winter et al., 2012b). Benthic $\delta 180$ is a proxy for global ice volume and deep sea temperature; vertical dashed lines mark benthic $\delta 180$ with present global ice volumes (gray) and projections for the last glacial maximum (LGM; blue) and peak Pliocene deglaciation (West Antarctica and Greenland melted; green) for comparison.

fication, light, nutrient and tracemetal availability, and a variety of other chemical and physical factors (e.g., Leventer et al., 1993; Leventer and Dunbar, 1996; Arrigo et al., 2003; Stickley et al., 2005; Denis et al., 2006; Tortell et al., 2008; Armbrust, 2009; Esper et al., 2010), making them excellent tracers of environmental change. Antarctic diatoms generally group into three ecologically circumscribed assemblages: those that thrive in the seasonal sea ice zone, those that thrive in the cold open ocean, and those that thrive in sub-Antarctic waters north of the polar front (Armand et al., 2005; Crosta et al., 2005; Romero et al., 2005). Abundance fluctuations of diatoms with varied environmental preferences in the marine sediment record allow the reconstruction of environmental variability through time (Armand, 2000).

Our environmental analysis focuses on two discrete diatomite units (DUs) within the late Pliocene "PRISM" interval (Fig. 2). DU IX (292.66- 283.35 mbsf; 3.2 Ma) and DU VIII (258.32-250.02 mbsf; $3.03 \mathrm{Ma}$ ) are each interpreted to record the interglacial component of a single $40 \mathrm{kyr}$ glacial/interglacial cycle (Scherer et al., 2007; Naish et al., 2009) during a geologic period of low-amplitude orbital variability. A new near-shore diatom biostratigraphic zonation developed from AND-1B places both units in the lower portion of the Fragilariopsis bohatyi partial range zone, 3.2 to $2.82 \mathrm{Ma}$ (Winter et al., 2012b). These two units have similar characteristic diatom assemblages dominated by Chaetoceros resting 


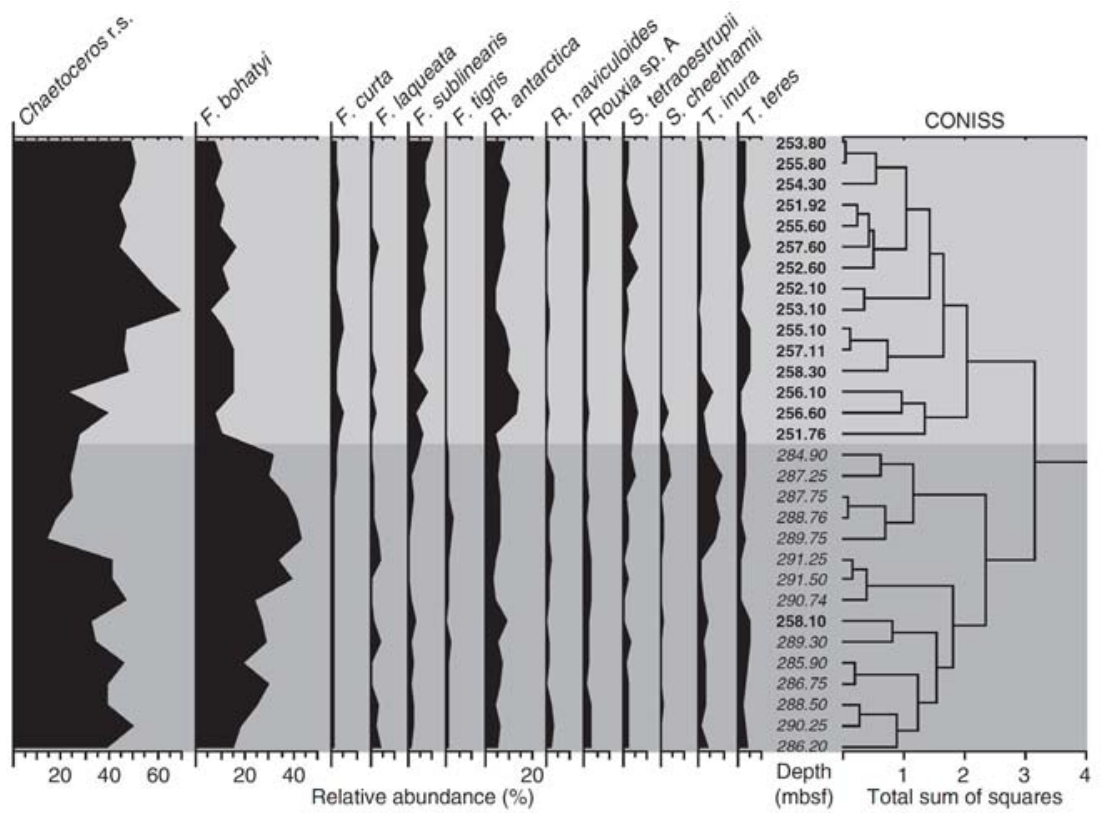

Figure 3. Incremental sum-of-squares cluster analysis (CONISS) of AND-1B DU IX and VIII diatom samples, unconstrained by depth and accompanied by relative abundance of dominant diatom taxa. The first two branches of the dendrogram, delineated by light gray and mid gray bars, distinguish DU IX (sample depths italicized) from DU VIII (sample depths in bold), with the exception of the DU VIII sample from 258.10 mbsf, which clusters with DU IX samples.

spores, distinguishing them from older and younger diatomites with lower Chaetoceros abundance (Scherer et al., 2007; Winter et al., 2010; Sjunneskog and Winter, 2012). The base of the lower unit is marked by the radiation of a Fragilariopsis species complex, including the nominate species of the new near-shore diatom zone, which is a primary constituent of the AND-1B late Pliocene diatom assemblage (Fig. 2). This complex is previously undescribed from Antarctic sediments, and may represent a precursor assemblage to the modern sea ice-associated members of the Fragilariopsis flora (Sjunneskog et al., 2012). Paleoenvironmental interpretation of DU IX and VIII relies on 1) environmental inferences from these two major constituents; 2) a smaller compo- nent of the assemblage that comprises extant species with well-established environmental preferences; and 3) inferred environmental affinities for extinct species with distributions that mirror those of extant species, or that have been employed in reconstructions from other Southern Ocean locations.

\section{Materials and methods}

Sedimentary biogenic silica concentrations (\%BSi) were measured using an alkaline extraction method modified from Strickland and Parsons (1976) to document sedimentary opal content from 292.76 to 242.60 mbsf and identify intervals for diatom assemblage

Table 1. Sample depth and chronostratigraphic control for AND-1B, 240-300 mbsf, following Naish et al. (2009) and Winter et al. (2012b), exceptFOT. vulnifica (**), which is identified in a deeper sample than previously reported. Cody et al. (2008) ages are from the CONOP average range model, and published ages are an average for each datum based on previously published Southern Ocean sites. An asterisk $\left(^{*}\right)$ next to first occurrence $(\mathrm{FO})$ or last occurrence (LO) indicates this datum is truncated by an unconformity. Ages marked by the $(\dagger)$ symbol are for new species identified from AND-1B and are first published in association with this core (Winter et al., 2012b).

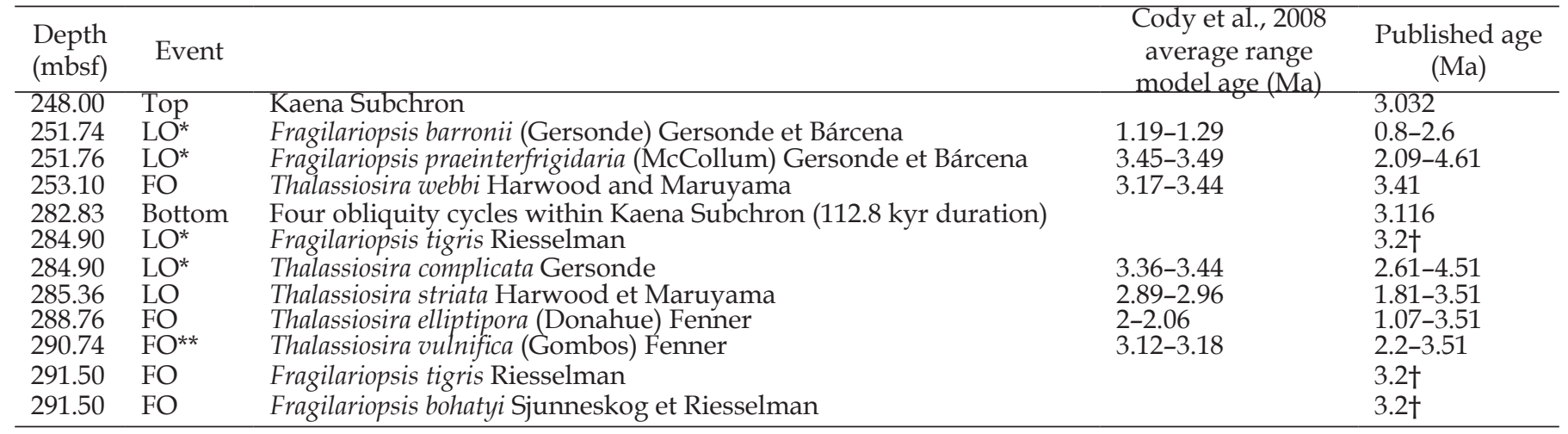


characterization. Sample spacing ranges from $\sim 4 \mathrm{~m}$ for diamictite intervals to $\mathrm{b} 0.3 \mathrm{~m}$ for diatomite intervals, as identified during the AND-1B core characterization effort (Krissek et al., 2007; Scherer et al., 2007). The average standard deviation for \%BSi of replicate samples within this group is $1.6 \%$, and average values are plotted in Fig. 2. In diatomites, BSi is generally between 50 and $65 \%$ by weight, while diamictite opal remains at a relatively high average concentration of $15 \%$. The upper portion of DU IX is characterized by a unique diatombearing muddy interval with $\mathrm{BSi}$ around $25 \%$ and moderate valve preservation (Table 2). On-ice microscopic characterization during drilling identified the common reworking of biosiliceous fragments into late Pliocene diamictites (Scherer et al., 2007), which supports the interpretation that "missing" interglacial cycleswere removed by subsequent grounding line advances (Naish et al., 2009) and redeposited in the matrix of glacigenic sediments. It is also possible that a portion of the relatively elevated silica concentration measured from the diamictites is derived from the dissolution of volcanic ash and/or glacially ground silts and clays (Liu et al., 2002).

For diatom assemblage studies, sample preparation methods were designed to facilitate comparison between workers and across units (Winter et al., 2010; Konfirst and Scherer, 2012; Konfirst et al., 2012; Sjunneskog et al., 2012; Sjunneskog and Winter, 2012; Winter et al., 2012b). 30 samples of approximately $2 \mathrm{~cm} 3$ volume were collected from the biosiliceous intervals DU IX $(n=14)$ and DU VIII $(n=16)$ at 0.5 to $1 \mathrm{~m}$ sample spacing (Fig. 2). Each semi-lithified sample was sub-sampled across its 1-cm depth, broken up by pressing gently with a mortar and pestle, digested in 3\% hydrogen peroxide for $12 \mathrm{~h}$ in a $30{ }^{\circ} \mathrm{C}$ water bath, triple-rinsed in NANOpure water and centrifuged for $2 \mathrm{~min}$ at $2000 \mathrm{rpm}$, then stored in NANOpure water. To prepare slides, samples were agitated and allowed to settle for $10 \mathrm{~s}$, then an aliquot of suspended material was dried onto a cover slip over a slide warmer, mounted using Norland optical adhesive No 61 (refractive index=1.56), and cured under UV light. The slides were examined on a Leica DM LB2 with Nomarski optics and equipped with 100x, 63×, and $40 \times$ oil-immersion objectives, attached to a SPOT Insight photomicrographic system, housed at the U.S. Geological Survey in Menlo Park, CA. Morphometric measurements were collected from LM images using the SPOT Basic software package when required to confirm species identifications. SEM images obtained using an FEI Sirion XL30 scanning electron microscope housed in the Stanford Nanocharacterization Laboratory were also employed to confirm ranges of selected species with biostratigraphic utility. While AND-1B sample preparation methods allow us to deal with the challenge of lithification, we acknowledge that these methods have likely resulted in some valve fragmentation. However, valve preservation and assemblage composition in the resulting strewn slides generally aligns with that of smear slides from similar depths that were generated for onice micropaleontologic assessment (Scherer et al., 2007), lending confidence that the overall assemblage has not been biased through preparation.

Finally, cluster analysis using the incremental sumof-squares CONISS method of Grimm (1987) was applied to diatom count data. In order to assess the extent to which DU VIII assemblages are distinct from DU IX assemblages, samples were stratigraphically unconstrained in this analysis, allowing each sample to amalgamate with any other sample or cluster (Fig. 3).

\section{Age control}

Diatom biostragraphy, magnetostratigraphy, and cyclostratigraphy provide primary age control for the AND-1B sediments accumulated between 292 and 250 mbsf (Table 1; Naish and Wilson, 2009; Wilson et al., 2007; Winter et al., 2012b). Based on available chronostratigraphic constraints, Naish et al. (2009) place DU IX at 3.2 Ma. This unit is unconformably overlain by $\sim 25$ $\mathrm{m}$ of sediments that preserve ice-proximal, grounding line, and subglacial siliciclastic facies. Within this siliciclastic sequence, four glacial surfaces of erosion (GSEs) mark the removal of intervening interglacial sediments by advancing grounded ice sheets on a cycle of $40 \mathrm{kyr}$, providing additional cyclostratigraphic control (Krissek et al., 2007; McKay et al., 2009; Naish et al., 2009). The top of DU VIII ( $252 \mathrm{mbsf})$ is just beneath the magnetic polarity reversal at the top of the Kaena Subchron, at 3.03 Ma (Wilson et al., 2007). A new diatombiostratigraphic scheme proposed from AND-1B, spanning the last $5 \mathrm{Myr}$, incorporates newly described species, established datums from existing near-shore sections, and pioneering work applying constrained optimization (CONOP) methods to Southern Ocean diatom assemblages (Cody et al., 2008; Winter et al., 2012b). Diatom datum ages reported from DU IX and DU VIII (Table 1) are largely those presented in Winter et al. (2012b), with the exception of the first occurrence (FO) of Thalassiosira vulnifica, which Winter et al. (2012b) report at 251.76 mbsf. The evolutionary divergence of this species from T. fasciculata is well preserved in AND-1B. While some early forms in DU IX and VIII exhibit morphologies ranging towards $T$. fasciculata, specimens that meet the species definition of T. vulnifica outlined by Mahood and Barron (1997) are consistently present at low abundances beginning at 290.74 mbsf. In addition, assemblages beginning at $288.76 \mathrm{mbsf}$ include a small number of T. vulnifica specimens with "conventional" morphologies (3-4 valve face fultoportulae with large, heavily silicified external structures; $3-4$ areolae rows in $10 \mu \mathrm{m}$ at margin). Based on the consistent presence of this species throughout DU IX and VIII, we amend its AND-1B 
Table 2. Fragmentation-related preservation, biogenic silica (\%), and relative abundance (\%) of diatom species and genera identified in DU IX and DU VIII, AND-1B. Preservation is reported on a good $(\mathrm{G}) / \mathrm{moderate}(\mathrm{M}) / \mathrm{poor}(\mathrm{P})$ scale, where $G$ indicates many whole valves, $M$ indicates many half valves, and $P$ indicates an absence of half valves.

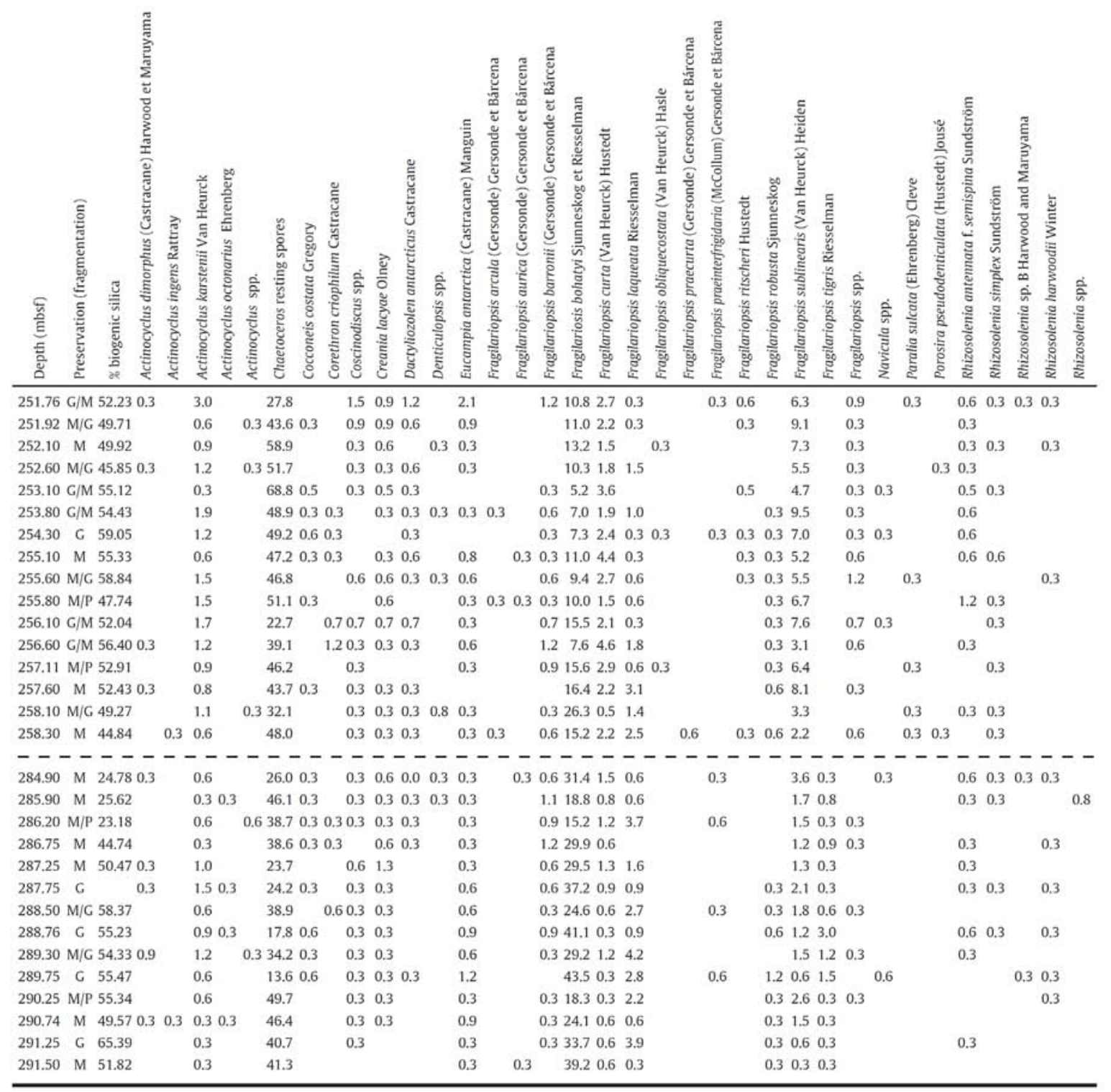

FO to 290.74 mbsf for the purposes of this investigation.

\section{Results}

The majority of species identified in assemblages from 14 DU IX samples and 16 DU VIII samples are common to both units, although the relative contributions of various assemblage constituents vary somewhat between the two (Table 2). Both assemblages are dominated by Chaetoceros resting spores and extinct species, including a previously undescribed complex of morphologies within the genus Fragilariopsis (Sjunneskog et al., 2012). While these two taxonomic groups are dominant, they are part of a diverse community of 23

species that each contribute $>2 \%$ relative abundance to individual samples in one or both assemblages (Fig. 4). Five of these are described as new species or identified with informal designations from AND-1B, and eight, excluding Chaetoceros spores, are extant. Overall, extant species are more abundant in DU VIII than in DU IX, while extinct species outside of the Fragilariopsis complex are equally abundant in both units (Fig. 2). These assemblages are distinct from the underlying diatomite unit, which is characterized by high relative abundances of the warm species Shionodiscus tetraoestrupii and Thalassionema nitzschioides and records an extended interval of open-ocean conditions from 3.6 to 3.4 Ma (Winter et al., 2010; McKay et al., 2012). 


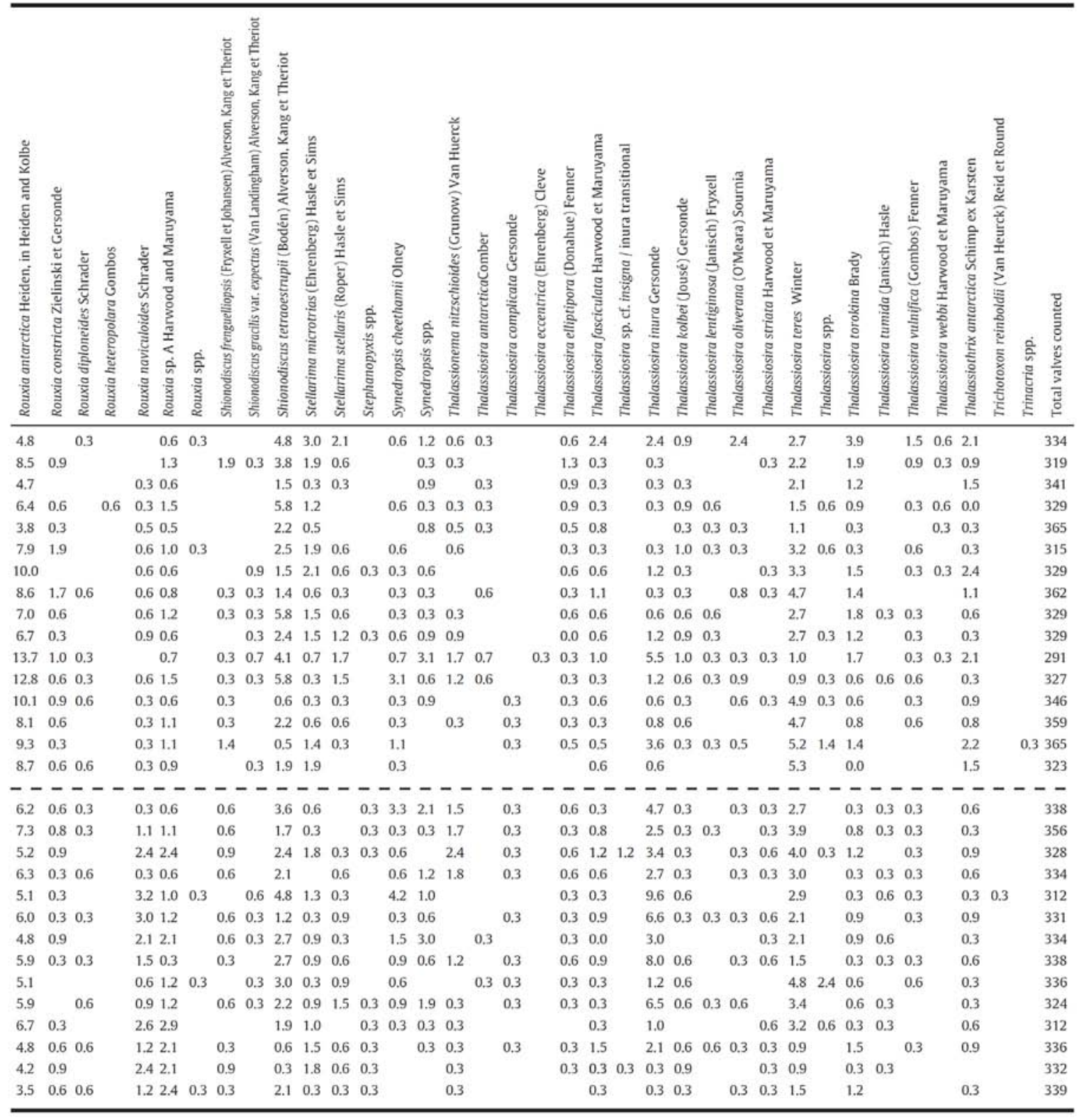

Overall, diatom valves in DU VIII and DU IX exhibit little evidence of dissolution under lightmicroscopy and SEM and some specimens even retain fine structures such as perforate poroidmembranes (Sjunneskog et al., 2012). Fragmentation-related preservation ranges from good to poor (Table 2), likely due to sediment and episodic glacial loading (Scherer et al., 2007). Fragmentation cuts across all species types, implying compaction rather than shearing or grazing (Scherer et al., 2004; Konfirst and Scherer, 2012). Because all species types are affected, we infer that variable preservation has not been a dominant factor in determining assemblage composition. The upper portion of DU IX is characterized by a decrease in sedimentary concentration of biogenic silica, from $\sim 50 \%$ to $\sim 25 \%$ (Fig. 2; Table 2). The greater proportion of terrigenous material in this $\sim 4 \mathrm{~cm}$-thick horizon is attributed to hemipelagic suspension settling due to proglacial processes, and is inferred to reflect grounding line advance at the close of the interglacial (Krissek et al., 2007; McKay et al., 2009). However, diatom assemblages in these lower-silica samples are not statistically distinguishable from the silica-rich samples below (Fig. 3) and the degree of fragmentation is similar (Table 2). This suggests that diatom deposition within the muddy interval is either 1) primary, with periodic outwash turbidity offset by intervals of primary production, or 2) indicative of a circulation pattern that carried local diatom blooms beneath a proximal ice shelf front. Both of these possibilities are supported by the sedimentary glaciomarine depositional models developed to describe AND-1B (McKay et al., 2009). 


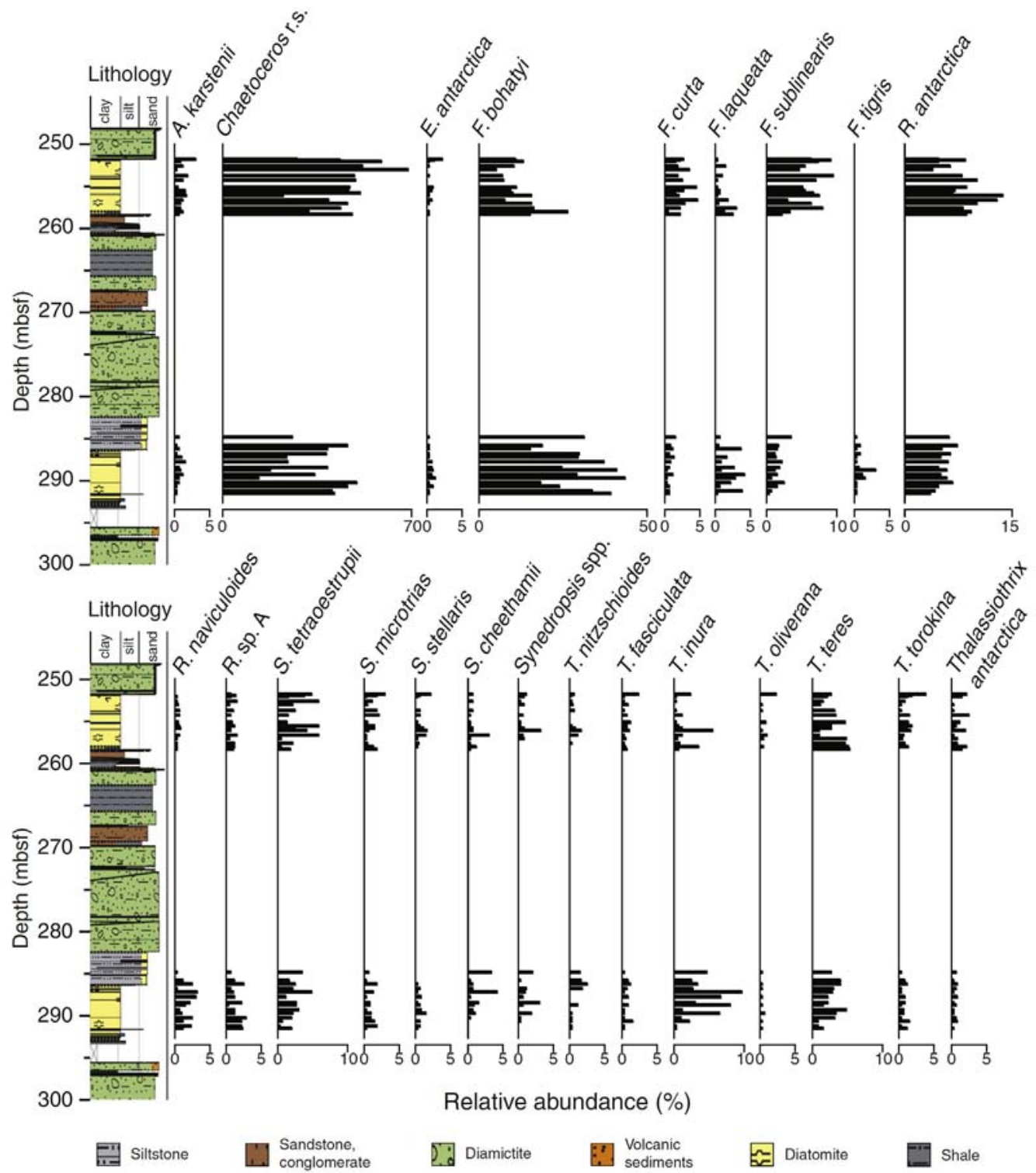

Figure 4. Relative abundances (\%) of diatom taxa present at $>2 \%$ in at least one AND-1B sample from DU IX and VIII. See figure 2 or the online version of this article for colored lithostratigraphy and key.

\subsection{Diatom unit IX, 291.50-284.90 mbsf, 3.2 Ma}

The DUIX assemblage preserves a dramatic change in Ross Sea diatom flora at 3.2 Ma. The lowermost sample, from 291.50 mbsf, contains the FOs of Fragilariopsis bohatyi Sjunneskog \& Riesselman and F. laqueata Riesselman, two species which are newly described from the AND- 1B Fragilariopsis complex (Sjunneskog et al., 2012). F. bohatyi appears at high relative abundance $(39 \%$ at $291.50 \mathrm{mbsf}$ ) and persists at high abundance (15-41\%) throughout DU IX (Table 2). The related species $F$. laqueata is present at much lower abundance $(0.3-4 \%)$ in all but one of the DU IX samples. The DU IX assemblage is also characterized by much greater Chaetoceros resting spore abundance $(14-50 \%)$ than is characteristic of older units (Scherer et al., 2007; Winter et al., 2010). Generally, lower abundances of this taxon are tabulated in the mid- dle of the unit; four of the eight samples with Chaetoceros resting spore abundance $>35 \%$ are clustered at the base of the unit and three are clustered near the top, though abundance declines to $26 \%$ in the uppermost sample. The assemblage includes a significant contribution from the extinct genus Rouxia, including $R$. antarctica (4-7\%), R. naviculoides (0.3-3\%), and a heteropolar spatulate form (Fig. 5) inferred to be R. sp. A of Harwood and Maruyama (1992) (0.3-3\%). Extinct centric species Shionodiscus tetraoestrupii $(0.3-5 \%)$, Thalassiosira inura $(0.3-10 \%)$, and the newly defined T. teres Winter (1-5\%) (Winter et al., 2012b) round out the DU IX characteristic assemblage; T. inura is most abundant in the middle of the unit, between 287.25 and 289.75 mbsf.

Fragilariopsis tigris Riesselman, another newly defined AND-1B species unrelated to the Fragilariopsis complex, 
is restricted to DU IX (Riesselman, in press); it is identified at low abundance $(0.3-3 \%)$ in all samples from this unit with maximum abundances of $1.2-3 \%$ clustered between 288.76 and 289.75 mbsf. F. tigris is previously documented only as a single fragment in a till sample $(\mathrm{UpB})$ recovered from beneath the Whillans Ice Stream (Scherer, 1991). DU IX and UpB also share an Actinocyclus form that is similar to Actinocyclus sp. cf. A. actinochilus (early form) of Harwood and Maruyama (1992). However, Harwood and Maruyama's form has a single central areola while the DU IX/UpB form, identified at low abundance $(\leq 0.6 \%)$ in half of DU IX samples, has a central cluster of areolae. The co-occurrence of these two taxa in both samples suggests that material similar to DU IX was deposited in the West Antarctic interior during the late Pliocene. A number of extant species with well-characterized ecological preferences are present at moderate to low abundance in all or nearly all samples, including Eucampia antarctica $(\leq 1.2 \%)$, Fragilariopsis curta $(\leq 1.5 \%)$, F. sublinearis $(\leq 4 \%)$, Stellarima microtrias $(\leq 1.8 \%)$, and Thalassiothrix antarcticac (b1\%). A similar group, present in at least half of the 14 DU IX samples, includes Rhizosolenia antennata $f$. semispina (b1\%), Stellarima stellaris $(\leq 1.5 \%)$, Thalassionema nitzschioides (b3\%), and Thalassiosira liverana (b1\%).

\subsection{Diatom unit VIII, 258.30-251.76 mbsf, 3.03 Ma}

The characteristic diatom assemblage in DU VIII is similar to that documented from DU IX, however the relative abundances of some key taxa vary between the two units. A variety of species with established environmental affinities, including Chaetoceros resting spores (23-69\%), Fragilariopsis curta $(0.5-5 \%)$, F. sublinearis (2-10\%), Rouxia Antarctica (4-14\%), Shionodiscus tetraoestrupii $(0.5-6 \%)$, and Thalassiothrix Antarctica $(\leq 2.4 \%)$ are more abundant in DU VIII than in IX. F. bohatyi (5-27\%), F. laqueata (0.3-3\%), R. naviculoides (b1\%), Rouxia sp. A $(\leq 1.5 \%)$, and T. inura $(0.3-6 \%)$ are less abundant. F. tigris is absent from DU VIII. T. teres $(0.9-5 \%)$ is present at similar abundances in both units; though peak abundance in DU IX is recorded from a single sample, this species is similarly abundant in DU VIII from 258.30 to $257.11 \mathrm{mbsf}$. The uppermost sample examined from DU VIII, at $251.76 \mathrm{mbsf}$, is unique within the unit. This sample has the maximum abundance of numerous species in all samples examined, including Actinocyclus karstenii (3\%), Coscinodiscus sp. (1.5\%), Eucampia antarctica (2.1\%), Stellarima microtrias (3\%), S. stellaris (2.1\%), Thalassiosira fasciculata $(2.4 \%)$, T. oliverana $(2.4 \%)$, T. torokina $(3.9 \%)$, T. vulnifica $(1.5 \%)$, and T. webbi $(0.6 \%)$. The richness of this sample is balanced by a comparatively low abundance of Chaetoceros resting spores (28\%). 5.3. CONISS analysis of DU IX and DU VIII. The incremental sumof-squares cluster analysis (CONISS) of AND-1B DU IX and VIII diatom samples is unconstrained by depth so that each sample is free to cluster with any other sam- ple. The first major split in the dendrogram identifies a statistical distinction between DU IX assemblages and DU VIII assemblages, with the exception of a single DU VIII sample that clusters with DU IX (Fig. 3). DU VIII samples cluster in the upper branch, which is higher in Fragilariopsis curta, F. sublinearis, and Rouxia antarctica while DU IX samples cluster in the lower branch, which is higher in the Fragilariopsis species that are newly defined from AND-1B and in R. naviculoides. Both branches include samples with high Chaetoceros abundance, although overall abundance is higher in the upper branch.

\section{Discussion}

Diatom assemblages from AND-1B provide three lines of evidence for the onset of Pliocene cooling at 3.2 $\mathrm{Ma}$, in the heart of the PRISM warm interval: 1) abundance of Chaetoceros resting spores; 2) radiation of new species within the Fragilariopsis genus; and 3) environmental affinities of well-characterized extant species (Armand et al., 2005; Crosta et al., 2005; Romero et al., 2005). In addition, environmental preferences for some extinct species common in AND-1B late Pliocene assemblages have Southern Ocean distributions that mirror extant environmental groupings (Abelmann et al., 1990; Barron, 1996a,b; Winter et al., 2010), providing support for environmental interpretations where extant species abundance is low. 6.1. Chaetoceros resting spores and ice melt stratification. Resting spores of the cosmopolitan genus Chaetoceros dominate AND-1B diatom assemblages from 3.2 Ma (average 34\%, maximum $50 \%$ ) and $3.03 \mathrm{Ma}$ (average $45 \%$, maximum $69 \%$; Table 2; Figs 2 and 6). Chaetoceros is also one of the most abundant diatom genera in the modern ocean, and is present in a range of environments from coastal temperate to polar regions (Armand et al., 2005). Of approximately 180 extant marine planktonic species, around 75 form resting spores (Stockwell and Hargraves, 1984); 25 Chaetoceros species are reported from Antarctic waters (Scott and Thomas, 2005). This fast-growing genus, indicative of high primary productivity at shallow depths, often dominates spring blooms in nutrient-replete environments such as coastal upwelling zones (Kemp et al., 2000). In the Antarctic, intense spring blooms of vegetative Chaetoceros are associated with stable, meltstratified surface waters (Leventer, 1991; Crosta et al., 1997, 2008; Leventer et al., 2006), where lowlight conditions through winter and capping by winter sea ice allow remineralized macronutrients to accumulate in the upper water column (Sweeney, 2003) and bioavailable iron may sometimes accumulate on the ice surface (e.g., Sedwick and DiTullio, 1997). Melt-induced spring blooms conclude when nutrient depletion triggers resting spore formation (Holm-Hansen and Mitchell, 1991); these spores are efficiently exported and preserved in 

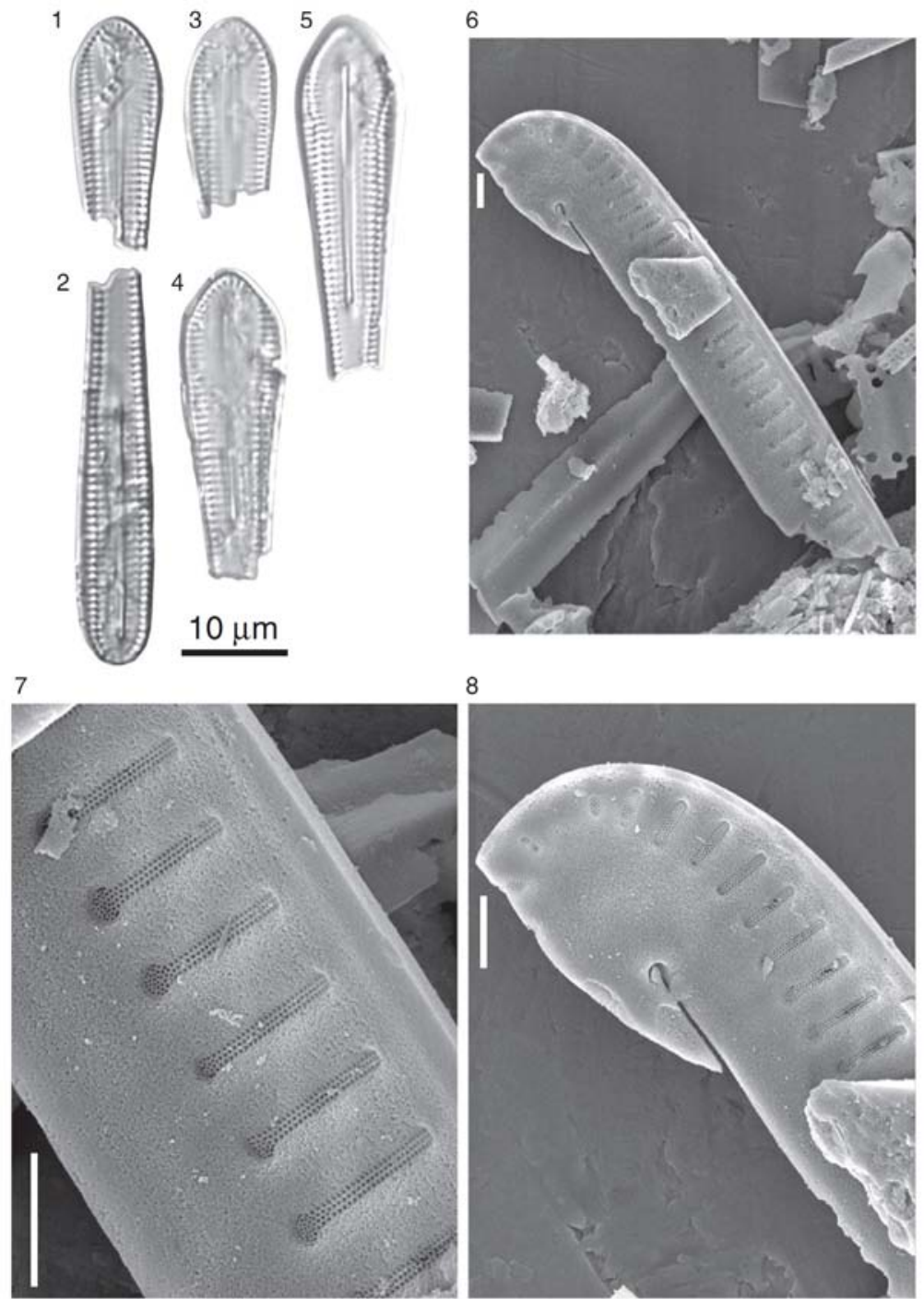

Figure 5. Rouxia sp. A LM and SEM micrographs from AND-1B: 1-2) 252.10 mbsf; 3) 255.10 mbsf; 4) 290.74 mbsf; 5) 292.50; 6-9) 288.75 mbsf, fragment and detail. $10 \mu \mathrm{m}$ scale bar applies to all LM micrographs; all scale bars for SEM micrographs are $1 \mu \mathrm{m}$.

Antarctic sediments. Chaetoceros relative abundances are commonly used to track high productivity events at the receding sea ice edge (Leventer and Dunbar, 1996; Denis et al., 2006). Both resting spores and vegetative cells are more commonly associated with pack ice than with fast ice (Ligowski et al., 1992; Scott et al., 1994). Although the value of tying resting spore morphologies to their vegetative counterparts is widely recognized (e.g., Suto, 2006 and references therein), they are currently lumped without species designation in bothmodern and paleoenvironmental investigations (Leventer et al., 1993, 2006; Crosta et al., 1997, 2008; Armand et al., 2005; Stickley et al., 2005; Esper et al., 2010).

Recent efforts have also linked physical oceanographic parameters such as SST and seasonal sea ice duration to the distribution of Chaetoceros resting spores in Antarctic surface sediments. An authoritative circumAntarctic synthesis of 228 core top samples associates
Chaetoceros abundances $>20 \%$ with peak summer SST between -1.3 and $3.5^{\circ} \mathrm{C}$, and with three to nine months annual sea ice duration; maximum relative abundances of $>90 \%$ occur with summer SST between -0.5 and $1.5^{\circ} \mathrm{C}$ (Armand et al., 2005; Fig. 6). A bimodal geographic distribution in Chaetoceros abundance has been identified in surface sediments from the Pacific sector of the Southern Ocean, with one peak within the zone of summer sea ice (summer SST around $-1{ }^{\circ} \mathrm{C}$ ) and a second peak north of the subantarctic front (summer SST around $6{ }^{\circ} \mathrm{C}$ ) (Esper et al., 2010). This bimodal distribution is also identified in the Atlantic sector, where Chaetoceros relative abundances $>50 \%$ are reported within the zone of seasonal ice melt, but also in a plume extending eastward from offshore Argentine Patagonia. In records of the most recent glacial interval from the same sector, abundances of $30-50 \%$ are restricted to the reconstructed seasonal sea ice zone (Abelmann et al., 2006). In the Ross Sea, 
Chaetoceros resting spores range from $20 \%$ of the surface sediment assemblage in the western part to $60 \%$ in the eastern, and have been used to trace stratification and peak productivity in the sediment record (Leventer et al., 1993; Crosta et al., 1997).

The environmental parameters outlined by Armand et al. (2005) indicate that three to nine months of annual sea ice cover provide optimum conditions for Chaetoceros growth and resting spore accumulation, and core top relative abundances above $20 \%$ are never recorded below this threshold. As noted above, Chaetoceros resting spores dominate the diatom assemblage in both PRISM-age late Pliocene diatomites at average abundances of $34 \%$ at $3.2 \mathrm{Ma}$ and $45 \%$ at $3.03 \mathrm{Ma}$ (Table 2; Figs 2 and 6), requiring that late Pliocene interglacial conditions support winter sea ice in the southwestern Ross Sea. Based on modern Antarctic distributions of the genus and on the ecological preferences expressed by extant members of the AND-1B assemblage (Section 6.3), we favor an interpretation in which abundant Chaetoceros resting spores at this site reflect intense bloom productivity in a nutrient-rich coastal water column stabilized by spring sea ice melt. Higher abundance of Chaetoceros resting spores in the upper and lower portions of the 3.2 Ma diatomite may indicate that glacial/ interglacial transitions supported a denser ice pack and more stratified water column than the peak interglacial, or that the summer sea ice edge and attendant zone of productivity retreated further south of AND-1B during this particular interglacialmaximum. Chaetoceros resting spores are more abundant at $3.03 \mathrm{Ma}$ than $3.2 \mathrm{Ma}$, suggesting greater ice-melt stratification and/or proximity to the ice edge with progressive cooling. This interpretation suggests a continental shelf environment fundamentally different from the Ross Sea today, in which a deeply mixed polynya is the locus of intense Phaeocystis-dominated spring productivity and the AND1B drillsite lies beneath a persistent floating ice shelf. However, the seasonally ice influenced environment inferred by Chaetoceros dominance at 3.2 and $3.03 \mathrm{Ma}$ is also much different than that recorded in mid-Pliocene ( 3.6-3.3 Ma) assemblages from the same core, where Chaetoceros resting spore abundance is generally below $16 \%$ and never greater than 26\% (Winter et al., 2010). 6.2. Fragilariopsis radiation in response to Pliocene cooling. The 3.2 Ma diatomite preserves the radiation of a complex of related Fragilariopsis morphologies previously undescribed from Antarctic sediments. Two new species described from this complex, F. bohatyi and $F$. laqueata (Sjunneskog et al., 2012), are morphologically similar and have similar distribution patterns in the two PRISM-age diatomites, although $F$. bohatyi abundances are an order of magnitude larger than F. laqueata abundances (Fig. 4). For this reason, environmental inferences are drawn for these species as a pair. The evolution and establishment of new species are commonly associated with environmental change (Berger, 2007). Diatoms in particular have diversified since the onset of Oligocene glaciation, with species richness peaking in the Pliocene (Falkowski and Oliver, 2007). In fact, trends in Cenozoic diatom diversity generally trace the global benthic $\delta 18 \mathrm{O}$ profile of deep sea cooling and continental ice accumulation (Zachos et al., 2001a; Marx and Uhen, 2010). It is therefore plausible that the diversification observed within the genus Fragilariopsis at 3.2 Ma occurred in response to Pliocene cooling. The late Pliocene Fragilariopsis complex is inferred to have evolved from F. praecurta and F. aurica, which in turn evolved during the late Miocene (Gersonde, 1989), a significant step in the global Cenozoic cooling trend (Zachos et al., 2001a). The concomitant decline of the F. praecurta group in the early Pliocene may then be related to an interval of relative warmth, culminating in the mid-Pliocene climate optimum ca. 3.6 Ma (Naish et al., 2009; Winter et al., 2010; Sjunneskog et al., 2012). Possibly this group persisted in small numbers in coastal refugia throughout the warmer mid-Pliocene, where Fragilariopsis spp. are rare in AND-1B (Naish et al., 2009; Winter et al., 2010), and late Pliocene cooling allowed the radiation of those forms that successfully adapted to the changing environment.

We propose, therefore, that the AND-1B Fragilariopsis flora reflects adaptive radiation in response to cooling in the Ross Sea through the late Pliocene (McKay et al., 2012). F. bohatyi appears at 3.2 Ma in high abundance (average 30\%, maximum $41 \%$ ), and declines in abundance at 3.03 Ma (average 12\%, maximum 26\%). F. laqueata has a similar distribution, but at much lower abundance (average $2 \%$, maximum $4 \%$ at $3.2 \mathrm{Ma}$; average $1 \%$, maximum $3 \%$ at $3.03 \mathrm{Ma}$ ). Although we interpret these two species as indicators of cooling, they decline in relative abundance as Chaetoceros (Section 6.1) and extant sea ice-affiliated taxa (Section 6.3) increase (Figs. 4 and 6). From this observation, we infer that $F$. bohatyi and F. laqueata prefer cool open ocean conditions not influenced by sea ice and may dominate the phytoplankton assemblage after the melt-induced spring Chaetoceros bloom is exhausted. 6.3. Environmental associations of extant species Extant taxa aside from Chaetoceros, comprising 25 species or species groups, are the least abundant component of the AND-1B diatom assemblage at 3.2 and 3.03 Ma (Figs. 2 and 6). Seventeen of these extant species have well-established environmental affinities, and eight are present at $>2 \%$ abundance in at least one sample. In addition, the extinct species Shionodiscus tetraoestrupii is considered with this group; its environmental affinity is presumed to be similar to that of extant descendant S. oestrupii (Winter et al., 2010; Winter et al., 2012b). The extant diatom assemblage is divided into four environmental groupings: 1 ) sea iceaffiliated species; 2) open ocean, ice-tolerant species; 3) open ocean, ice-intolerant species; and 4) subantarctic 
A

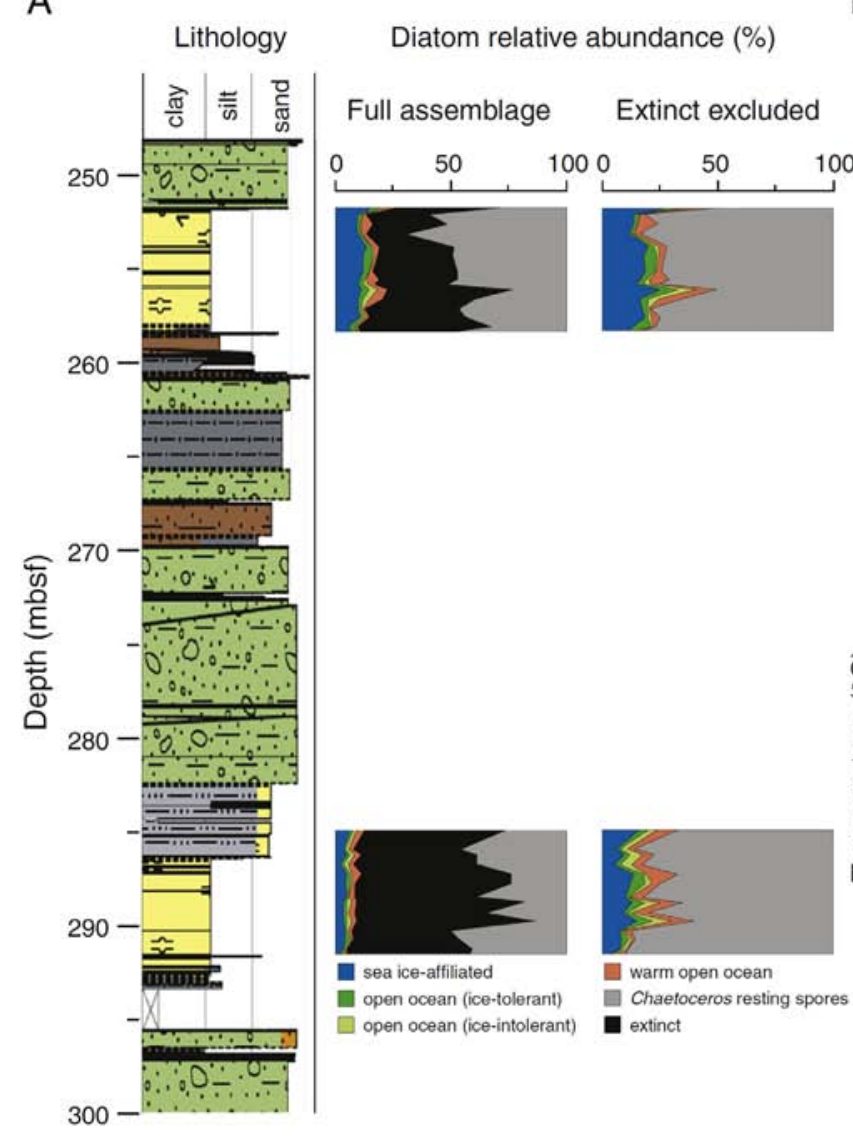

B

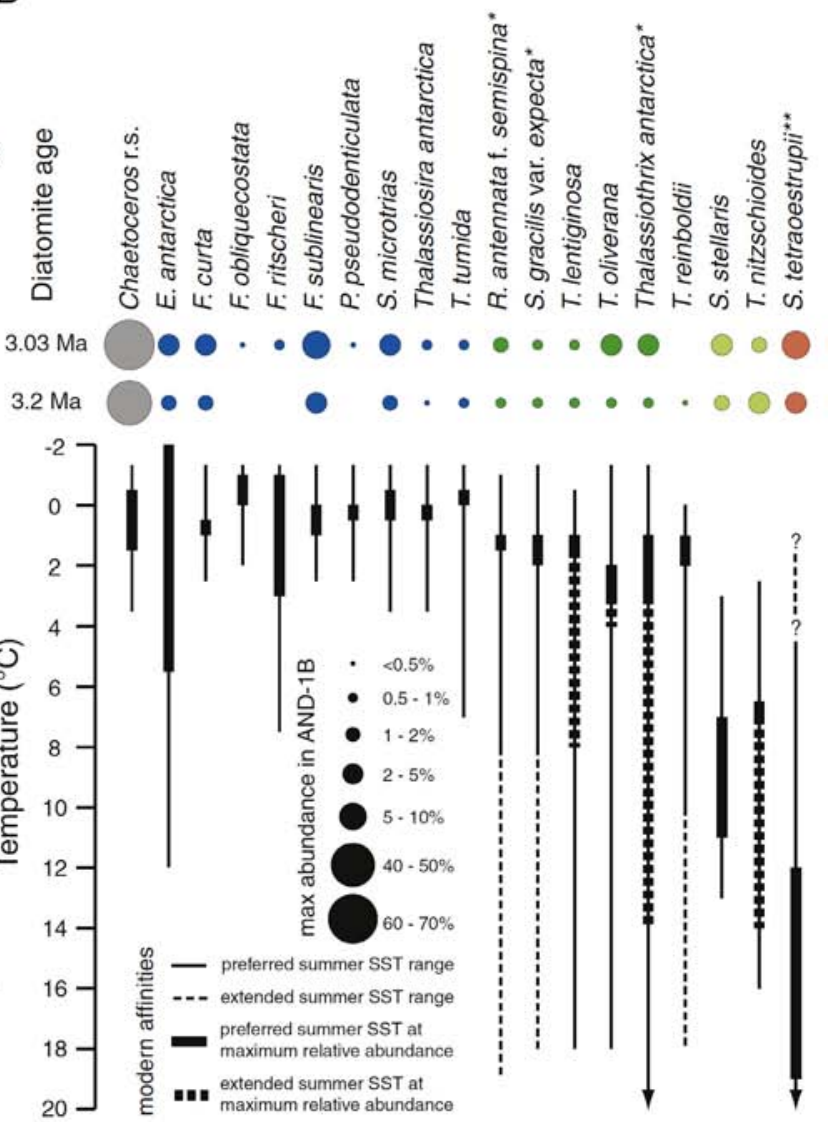

Figure 6. Summary of environments associated with AND-1B late Pliocene diatom assemblages: A) Lithologic log and relative abundance of diatoms, grouped by ecological affinity. Left assemblage panel incorporates all relative abundance data from Table 2; right assemblage panel subtracts extinct species and normalizes the remainder to 100\%. B) Modern summer temperature ranges for the species that comprise ecological groups in "A". Circles beneath taxon names are sized according to the maximum relative abundance of each species identified in interglacial diatom assemblages from $3.2 \mathrm{Ma}$ and $3.03 \mathrm{Ma}$ (see Fig. 4, Table 2). Temperature ranges and preferences for Chaetoceros resting spores and sea ice-affiliated species after Armand et al. (2005), except E. antarctica, which comes from Zielinski and Gersonde (1997). Temperature ranges and preferences for open ocean species after Crosta et al. (2005), where species marked with an asterisk $\left(^{*}\right)$ are members of broader taxon groups. That publication identifies "preferred" SSTs in the text but provides extended temperature ranges in a table, and both data sets are presented here. Temperature range for the subtropical extant species Shionodiscus oestrupii after Romero et al. (2005). Theancestral S. tetraoestrupii $\left(^{* *}\right)$ is the species identified in AND-1B and may have preferred a cooler environment than its modern descendant; "?" at $1{ }^{\circ} \mathrm{C}$ marks minimum temperature tolerance proposed by Whitehead et al. (2001).

open ocean species. Ecological designations follow the comprehensive three part biogeographic investigation of Armand et al. (2005), Crosta et al. (2005), and Romero et al. (2005), with constraints for two additional species from Zielinski and Gersonde (1997) and Armand (1997) (Fig. 6). Extant species affiliated with sea ice are the largest and most diverse ecologically-constrained constituent in the AND-1B assemblage at both 3.2 and $3.03 \mathrm{Ma}$. Grouped sea ice taxa are less abundant at 3.2 Ma (average $4 \%$, maximum 6\%), and increase significantly in abundance at $3.03 \mathrm{Ma}$ (average $11 \%$, maximum 15\%; Fig. 6A). Fragilariopsis curta, F. sublinearis, Stellarima microtrias, Thalassiosira antarctica, and T. Tumida are present at trace to moderate abundances in both diatomites, while F. obliquecostata, F. ritscheri, and Poro- sira pseudodenticulata are only present, albeit at trace abundance, in the $3.03 \mathrm{Ma}$ assemblage. The Armand et al. (2005) synthesis of core top abundance, SST, and sea ice duration and concentration equates this group with preferred summer SST between-1 and ${ }^{\circ} \mathrm{C}$ (Fig. 6B). Maximum abundances of these species occur in surface sediments where annual sea ice duration ranges from 7 to 11 months cover, and with up to $40 \%$ summer sea ice concentrations. Eucampia antarctica has a more cosmopolitan distribution in the Southern Ocean (e.g., Esper et al., 2010) and is excluded from the Armand et al. (2005) sea ice species group. However, the species is considered here, with ecological constraints from Zielinski and Gersonde (1997), for consistency with reconstructions of AND-1B cool intervals in the early Pliocene (Chow, 
2010), prior to the evolution of most established sea ice taxa. It is present at trace abundance in most DU IX and VIII samples and only contributes significantly $(2.1 \%)$ to the uppermost sample of the 3.03 Ma diatomite. In all, nine species comprise the sea ice assemblage at 3.03 Ma. Six ice-tolerant open ocean species (Crosta et al., 2005) comprise the second ecological grouping in AND-1B. As with sea ice-affiliated species, this group is more abundant at $3.03 \mathrm{Ma}$ (average 2.2\%, maximum 5\%), than at 3.2 Ma (average 1.2\%, maximum 1.5\%), and comprises Rhizosolenia antennata $f$. semispina, Shionodiscus gracillis var. expectus, Thalassiosira lentiginosa, T. oliverana, and Thalassiothrix antarctica. A single apex of Trichotoxon reinboldii is also identified from DU IX. Crosta et al. (2005) sometimes lump multiple similar species or forms into "species groupings" (i.e., "Rhizosolenia pointed group"); individual constituent species are identified here. In this analysis, three "cool open ocean" and three "pelagic open ocean" taxa of Crosta et al. (2005) are considered together: although "cool open ocean" species are identified within the maximum winter sea ice edge and "pelagic open ocean" are identified at the APF, all six exhibit a tolerance for low concentrations of summer sea ice. It should also be noted that $S$. gracilis var. expectus specimens identified from this material are much older than the reported range for $S$. gracilis (FO $\sim 2 \mathrm{Ma}$; Cody et al., 2008). Refer to Section 9 (Taxonomic notes) for discussion.

Two ice-intolerant open ocean species, Stellarima stellaris and Thalassionema nitzschioides (Armand, 1997; Crosta et al., 2005), comprise the third ecological grouping in AND-1B. This group is present in similar abundance at $3.2 \mathrm{Ma}$ (average 1.2\%, maximum5\%) and 3.03 Ma (average 1.1\%, maximum 3\%). Because extant species are generally less abundant at $3.2 \mathrm{Ma}$, this group is comparatively more important in interpretation of the older interval. Only T. nitzschioides represents this group according to Crosta et al. (2005), but S. stellaris distribution from a much smaller number of samples documents environmental preferences that are very similar to T. nitzschioides (Armand, 1997). In modern core tops, these two species have maximum abundances near the $\mathrm{APF}$, north of the winter sea ice maximum where summer SST is $6-7^{\circ} \mathrm{C}$ (Armand, 1997; Crosta et al., 2005).

No extant species with subantarctic ecological preferences (Romero et al., 2005) are identified in late Pliocene AND-1B sediments. However, the extinct species Shionodiscus tetraoestrupii is inferred to share environmental preferences with its extant ancestor S. oestrupii (McKay et al., 2012; Winter et al., 2012b). Shionodiscus tetraoestrupii is present in moderate abundance at both 3.2 Ma (average 2.2\%, maximum 5\%) and $3.03 \mathrm{Ma}$ (average $2.9 \%$, maximum 6\%). The modern S. oestrupii is present at relative abundances up to $5 \%$ only in the Atlantic Ocean north of the Subantarctic Front, where summer SST is greater than $11{ }^{\circ} \mathrm{C}$. However, this cos- mopolitan species has been recorded as far north as the Norwegian Sea and as far south as the Weddell Sea (Fryxell and Hasle, 1980; Romero et al., 2005). Shionodiscus tetraoestrupii is present throughout the AND-1B core, co-occurring with species that have much cooler modern ecological constraints (Scherer et al., 2007; Winter et al., in 2012b). In fact, Whitehead et al. (2001) propose a minimum temperature tolerance of $1^{\circ} \mathrm{C}$ for this species from Pliocene material, and suggest that its ecology may range toward sea ice tolerance as well. Shionodiscus tetraoestrupii is included in this investigation to maintain consistency with ongoing efforts to summarize AND-1B diatom paleoenvironmental interpretations (McKay et al., 2012), however ecological associations of this fossil species are as of yet unclear (Winter et al., 2012b).

Environmental inferences drawn from extant diatom assemblages are in good agreement with those from Chaetoceros resting spores and the Fragilariopsis radiation. All three lines of evidence indicate the onset of surface ocean cooling with winter sea ice cover at $3.2 \mathrm{Ma}$, followed by further cooling and possibly regional persistence of some summer sea ice at $3.03 \mathrm{Ma}$. No modern analog for this environment has been identified in the Antarctic. Sediment trap studies of modern Ross Sea diatom assemblages indicate that diatom flux to the sediments is dominated by F. curta (up to $92 \%$ ), with secondary contributions by other robust Fragilariopsis species such as F. cylindrus, F. obliquecostata, and F. ritscheri, Chaetoceros spp., Thalassiosira antarctica, and T. gracilis (Leventer and Dunbar, 1996). A similar assemblage from Ross Sea core tops (Truesdale and Kellogg, 1979) is characteristic of neritic production within a fully developed, cold polar sea ice regime. Though many of these species are also present in AND-1B, it is crucial to emphasize that the modern sea ice assemblage of Armand et al. (2005) is never identified in these sediments.

\subsection{Environmental associations of extinct species}

Although ecological preferences of extinct species are inferred rather than observed, a number of extinct taxa have acknowledged environmental affinities that are commonly used in paleoenvironmental reconstructions. Rouxia antarctica, one of the most frequently utilized extinct species (Abelmann et al., 1990; Barron, 1996b; Whitehead and McMinn, 2002; Winter et al., 2010; Konfirst et al., 2011), is common in AND-1B. This species has been associated with pack ice and cold surface ocean conditions in the Pleistocene (Whitehead and McMinn, 2002); in Pliocene reconstructions, it is employed to identify Antarctic waters south of the Polar Front (Abelmann et al., 1990; Barron, 1996b). Rouxia antarctica distribution patterns in late Pliocene AND-1B sediments are similar to Chaetoceros resting spores and grouped sea ice-affiliated species (Figs. 4 and 6). Rouxia antarctica is more abundant at $3.03 \mathrm{Ma}$ (average $8 \%$,maximum $14 \%$ ) than at $3.2 \mathrm{Ma}$ (average $5 \%$, maximum $7 \%$ ). Its co-occur- 
rence with taxa that have well-characterized preferences for cold, icy, stratified surface waters supports a similar ecology for this extinct species.

\subsection{Temperature inferences from extant species}

Sea surface temperature in the Ross Sea today typicaSea surface temperature in the Ross Sea today typically ranges from -1.8 to $1{ }^{\circ} \mathrm{C}$ (Sweeney, 2003), although peak summer temperatures between 3 and $4{ }^{\circ} \mathrm{C}$ have been recorded in the thermally stratified surface waters of the western Ross Sea (Dunbar et al., 2006). A low-diversity diatom assemblage dominated by species such Fragilariopsis curta and F. cylindrus reflects the minimal seasonal variability in SST in this modern environment. In contrast, the diverse late Pliocene assemblage recovered from AND-1B includes species with various, and sometimes contradictory, temperature preferences (Fig. 6B). However, some inferences on SST during the window of seasonal productivity can be drawn from the extant species identified from AND-1B.

Chaetoceros resting spores are the most abundant ecologically constrained element of the $3.2 \mathrm{Ma}$ assemblage (average 34\%, maximum 50\%) and the single most abundant diatom group in the $3.03 \mathrm{Ma}$ assemblage (average $45 \%$, maximum 69\%). In modern circum-Antarctic core tops, Chaetoceros resting spores peak at 92\%; abundances $>20 \%$ are only found where maximum summer SST is colder than $2{ }^{\circ} \mathrm{C}$, although they persist in lower abundance to $3.5^{\circ} \mathrm{C}$ (Armand et al., 2005). This distribution likely reflects the interplay of various environmental factors. Nutrient availability and water column stabilization associated with melting sea ice may influence Chaetoceros abundance as much as SST, while sea ice processes themselves are associated with cold surface waters. The Chaetoceros/SST correlation may therefore be a reflection of the Chaetoceros/sea ice correlation. Fragilariopsis sublinearis is the extant taxon with the next greatest abundance in AND-1B. As with Chaetoceros resting spores, this species is more abundant at $3.03 \mathrm{Ma}$ (average 6.1\%, maximum 9.5\%) than at $3.2 \mathrm{Ma}$ (average $1.5 \%$, maximum $3.6 \%$ ). In fact, average F. sublinearis relative abundance at $3.03 \mathrm{Ma}$ is equivalent to the maximum relative abundance recovered from modern circum-Antarctic core tops (Armand et al., 2005). In the modern assemblage, $F$. sublinearis abundance $\geq 4 \%$ is restricted to a narrow maximum summer SST range of $0-1{ }^{\circ} \mathrm{C}$, while lower abundances are found between -1.3 and $2.5^{\circ} \mathrm{C}$. Interestingly, peak relative abundances of both Chaetoceros resting spores and F. sublinearis in coretop assemblages are correlated with $\sim 7$ months of sea ice cover annually (Armand et al., 2005). A temperature of $\leq-1.9^{\circ} \mathrm{C}$ is required to freeze seawater, providing a bounding winter SST for these units.

Covarying high relative abundances of these two taxa suggest that summer SSTs in the southern McMurdo Sound were $\leq 1{ }^{\circ} \mathrm{C}$ during the late Pliocene, perhaps 1-2
${ }^{\circ} \mathrm{C}$ warmer than modern Ross Sea temperatures. This estimate is in good agreement with modern/late Pliocene SST offsets proposed for other sites around the Antarctic (Barron, 1996a), is within the range of summer SSTs documented for all members of the diverse sea ice-affiliated and ice-tolerant open ocean assemblages identified in AND-1B (Armand et al., 2005; Crosta et al., 2005), and is at the upper bound of SSTs proposed for the subantarctic fossil taxon Shionodiscus tetraoestrupii (Whitehead and McKelvey, 2001). Although the diatomite at $3.03 \mathrm{Ma}$ is interpreted to have been deposited under cooler summer temperatures and/or greater sea ice influence than the $3.2 \mathrm{Ma}$ diatomite, gross assemblage similarities prevent us from estimating a temperature difference between the two.

However, the ice-intolerant open ocean taxa Stellarima stellaris and Thalassionema nitzschioides are restricted to modern environments where summer SSTs do not fall below 3.0 and $2.5{ }^{\circ} \mathrm{C}$ respectively (Armand, 1997; Crosta et al., 2005). The ecological preferences of S. stellaris have been characterized at a relatively small number of sites and may be broader than reported. Thalassionema and Thalassiothrix specimens in AND-1B were identified from apical fragments; in samples with heavily fragmented or poorly preserved assemblages, it is possible that a small number of Thalassiothrix antarctica apices were misidentified as T. nitzschioides. However, this does not reconcile the temperature disagreement for specimens that were identified with certainty. While we favor the temperature estimate fit from abundant Chaetoceros and Fragilariopsis sublinearis, we acknowledge that T. nitzschioides indicates a somewhat warmer surface ocean.

\section{Onset of Ross Sea cooling during an interval of global warmth}

The onset of late Pliocene cooling in the Ross Sea coincides with the beginning of the global "warm" interval (3.264-3.025 Ma) that has been the focus of PRISM reconstruction efforts. The three-dimensional PRISM reconstruction of global ocean temperature (Dowsett et al., 2009, 2012) identifies dramatic warm departures from modern temperatures in the North Atlantic surface ocean and in upwelling zones, moderate warm anomalies at north and south mid-latitudes, and slight warm anomalies at the equator and in the highest southern latitudes around the Antarctic continent. The minimally warmer-than-present SSTs we propose at AND-1B at 3.2 and $3.03 \mathrm{Ma}$ are in line with this global reconstruction and provide an ice-proximal reference point in the growing body of evidence that the Southern Ocean began to cool even as Pliocene warmth lingered in the Northern Hemisphere (Fig. 7). This evidence includes complementary continuous, orbitally-tuned alkenone SST reconstructions from $45^{\circ} \mathrm{S}$ in the South Atlantic 


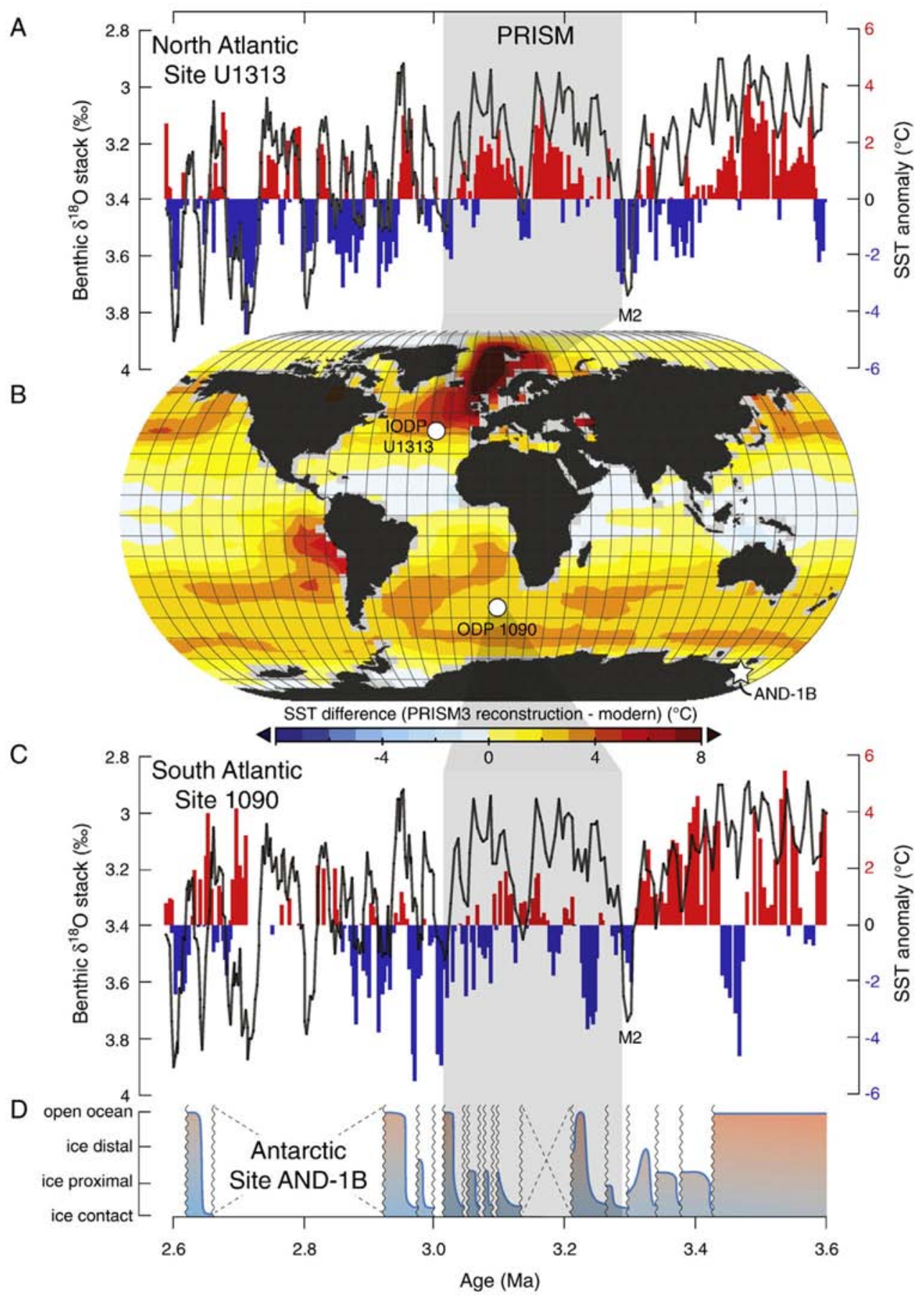

Figure 7. Climate indicators across the onset of Pliocene cooling; gray bar marks the PRISM interval. A) LR04 benthic oxygen isotope stack (Lisiecki and Raymo, 2005) plotted against Piacenzian SST anomaly for subarctic Atlantic IODP Site U1313. Anomaly was calculated by subtracting the Piacenzian (3.6-2.59 Ma) mean from the alkenone-based SST values of Naafs et al. (2010). B) Estimated late Pliocene (3.264-3.025 Ma) austral summer (1 December) SST difference from modern, based on the PRISM3 reconstruction. Location of AND-1B drillsite is indicated by a white star; comparative sites IODP U1313 and ODP 1090 are indicated by white circles. Diatom-based SST estimates at 3.2 and 3.03 Ma from AND-1B are in good agreement with the modest warming near the Antarctic continent identified in PRISM3. Pliocene continental configuration overlay from NASA GISS Panoply Data Viewer; SST anomaly data from Dowsett et al. (2009). C) SST anomaly of subantarctic Atlantic Site 1090 (Martínez-Garcia et al., 2011), plotted as in panel A. D) AND-1B glacial proximity curve of Naish et al. (2009), plotted against age. U1313 Piacenzian SST anomalies indicate extended North Atlantic warmth during the PRISM interval, and are generally coherent with the benthic $\delta 180$ stack following the M2 glaciation at $3.3 \mathrm{Ma}$. In contrast, Site 1090 SST anomalies decouple from the benthic $\delta 180$ stack followingM2 and are generally cool across the PRISM interval, at a time when AND1B diatom assemblages and sedimentologic indicators of glacial proximity both record the onset of cooling in the Ross Sea. 
(ODP Site 1090;

Martínez-Garcia et al., 2011 ) and $41^{\circ} \mathrm{N}$ in the North Atlantic (IODP Site U1313; Naafs et al., 2010). These subpolar records diverge after $\sim 3.5 \mathrm{Ma}$ and exhibit opposing trends across the large positive $\delta 18 \mathrm{O}$ excursion associated with theM2 glacial advance at $3.3 \mathrm{Ma}$ (Lisiecki and Raymo, 2005). Mean SST at subarctic Site U1313 warms significantly into the PRISM interval following the M2 event, and subsequently exhibits variance that closely mirrors the benthic $\delta 18 \mathrm{O}$ stack. In contrast, as with AND-1B, peak Pliocene warmth at subantarctic Site 1090 is restricted to the interval preceding M2 and cooling is well underway by the start of the PRISM interval.

Finally, the relatively small departure from modern Southern Ocean temperature at AND-1B belies the significance of the dramatic oscillations in West Antarctic Ice Sheet volume, in response to relatively modest forcing, that are implied by the grounded ice/open ocean cycles that accompany Antarctic cooling at 3.2 Ma (Naish et al., 2009; McKay et al., 2012). In fact, the AND1B core provides striking evidence for the repeated destabilization of the West Antarctic Ice Sheet at a time when its marine margin was only slightly warmer than today. This responsiveness underscores the value of considering late Pliocene climate reconstructions as we attempt to constrain the potential range of global responses to future warming. Furthermore, the agreement between our new record and the comprehensive Pliocene

PRISM reconstruction does not address the influence that a cooling Antarctic margin and evolving cryosphere might have exerted on a warmer globe. The preservation of cooler temperatures at AND-1B and Site 1090 during the PRISM interval suggests that theM2 glaciation at 3.3 Mamay have surpassed a climate threshold for the Antarctic, cooling the Southern Hemisphere and preconditioning the globe for the later onset of Northern Hemisphere glaciation. Future efforts to constrain the interplay between continental conditions and Antarctic sea ice, and to understand the relationship between Pliocene sea ice and deep water production, may ultimately allow us to better address the role of leads and lags in questions of warming and cooling.

\section{Summary and conclusions}

Diatom assemblages recovered by the ANDRILL Program from the southern McMurdo Sound provide multiple indications of late Pliocene cooling in the Ross Sea at 3.2 Ma, following an extended interval of openocean conditions from 3.6 to 3.4 Ma (Winter et al., 2010). This interpretation is supported by sedimentologic evidence that grounded ice, absent from the drillsite beginning at $\sim 4.5 \mathrm{Ma}$, reappeared at $\sim 3.3 \mathrm{Ma}$ (McKay et al., 2009; Naish et al., 2009) and by geochemical evidence for the initiation of glacial/interglacial productivity cycles at 3.2 Ma (McKay et al., 2012). Pliocene cooling in the Ross Sea precedes the onset of Northern Hemisphere glaciation and was accompanied by a radiation of the diatom genus Fragilariopsis. Although diatombased estimates from AND-1B (this work) and other circum-Antarctic sites (Barron, 1996a,b; Dowsett et al., 2012) indicate that Antarctic SSTs were only modestly warmer than present during the interval from 3.3 to 3.0 Ma, AND-1B sediments provide evidence for orbital oscillations of the Ross Ice Shelf and WAIS during this best-analog window into our planet's future.

\section{Floral list and taxonomic notes}

Formal citations for species identified in AND-1B DU IX and VIII are provided below, along with remarks and references to representative illustrations where appropriate. The reader is referred to these references for a thorough taxonomic treatment:

Actinocyclus dimorphus (Castracane) Harwood et Maruyama

Representative illustrations: Harwood and Maruyama (1992) plate 12, figs. 9 and 10; Scherer (1991), plate 3 , fig. 2

Actinocyclus dimorphus (Castracane) Harwood et

Maruyama

Actinocyclus ingens Rattray

Actinocyclus karstenii Van Heurck

Actinocyclus octonarius Ehrenberg

Actinocyclus spp.

Chaetoceros resting spores

Cocconeis costata Gregory

Corethron criophilum Castracane

Coscinodiscus spp.

Creania lacyae Olney

Dactyliozolen antarcticus Castracane

Denticulopsis spp.

Remarks: likely reworked

Eucampia antarctica (Castracane) Manguin

Fragilariopsis arcula (Gersonde) Gersonde et Bárcena

Fragilariopsis aurica (Gersonde) Gersonde et Bárcena

Fragilariopsis barronii (Gersonde) Gersonde et Bárcena

Remarks: This species exhibits wide morphologic variability, as previously reported from Kerguelen Plateau by Whitehead and McMinn (2002) and from Prydz Bay by Whitehead and Bohaty (2003). In assemblages from AND-1B DU IX and VIII, we apply a broad taxonomic concept to this species, including both forms that adhere to F. barronii sensu stricto of Gersonde (1989) and forms described by Whitehead and McMinn as F. barronii var A, which have a valve outline intermediate between F. barronii and F. ritscheri.

Representative illustrations: Zielinski and Gersonde (2002) plate 1, figs. 29-31; Zielinski and Gersonde (2002) 
plate 1, fig. 27(as F. barronii / kerguelensis transitional form); Harwood and Maruyama (1992) plate 17, fig. 27

Fragilariopsis bohatyi Sjunneskog et Riesselman

Representative illustrations: Sjunneskog et al. (2012) plates 3 and 4; Winter et al. (2012b) figure 5, nos. 1-3; Bohaty et al. (1998) plate 1, figs. 11 and 13 (as Fragilariopsis sp.)

Fragilariopsis curta (Van Heurck) Hustedt

Fragilariopsis laqueata Riesselman

Representative illustrations: Sjunneskog et al. (2012) plates 1 and 2

Fragilariopsis obliquecostata (Van Heurck) Hasle

Fragilariopsis praecurta (Gersonde) Gersonde et Bárcena

Fragilariopsis praeinterfrigidaria (McCollum) Gersonde et Bárcena

Fragilariopsis ritscheri Hustedt

Fragilariopsis robusta Sjunneskog

Representative illustrations: Sjunneskog et al. (2012) plates 5 and 6

Fragilariopsis sublinearis (Van Heurck) Heiden

Representative illustrations: Hasle (1965) plate 7, fig. 1 and plate 11

Fragilariopsis tigris Riesselman

Representative illustrations: Riesselman (in

press) plates 1 and 2; Scherer (1991) plate III, fig. 8 (as

Nitzschia sp. A)

Fragilariopsis spp.

Navicula spp.

Paralia sulcata (Ehrenberg) Cleve

Porosira pseudodenticulata (Hustedt) Jousé

Rhizosolenia antennata $f$. semispina Sundström

Rhizosolenia simplex Sundström

Rhizosolenia sp. B Harwood and Maruyama

Rhizosolenia harwoodii Winter

Representative illustrations: Winter et al. (2012b)

figure 5, no. 18; Harwood and Maruyama (1992) plate

18, figs. 7-10 (as Rhizosolenia sp.D)

Rhizosolenia spp.

Rouxia antarctica Heiden, in Heiden and Kolbe

Rouxia constricta Zielinski et Gersonde

Remarks: There are many specimens throughout AND-1B that have elongate, tapered ends yet do fitwithin the definitions of either R. constricta or R. leventerae. As $R$. isopolica has been synonomized with $R$. constricta, we group all specimens of this general morphology into this species.

Rouxia diploneides Schrader

Rouxia heteropolara Gombos

Rouxia naviculoides Schrader

Rouxia sp. A Harwood and Maruyama

Representative illustrations: Harwood and Maruyama (1992) plate 19, fig. 11; this manuscript, Fig. 4

Rouxia spp.
Shionodiscus frenguelliopsis (Fryxell and Johansen)

Alverson, Kang et Theriot

Shionodiscus gracilis var. expectus (Van Landingham)

Alverson, Kang et Theriot

Remarks: Specimens conforming to the taxonomic concept of Johansen and Fryxell (1985) in the number, distribution, and visibility of marginal strutted processes and in the pattern of valve face areolation are identified in AND-1B DU IX and VIII. This material is much older than the reported range of the species in the literature.

Representative illustrations: Johansen and Fryxell (1985) page 167, figs. 60-61 (as Thalassiosira gracilis var. expecta); Bohaty et al. (1998) plate 4, fig. 7 (as Thalassiosira gracilis var. expecta)

Shionodiscus tetraoestrupii (Bodén) Alverson, Kang et Theriot

Stellarima microtrias (Ehrenberg) Hasle et Sims

Stellarima stellaris (Roper) Hasle et Sims

Stephanopyxis spp.

Synedropsis cheethamii Olney

Synedropsis spp.

Thalassionema nitzschioides (Grunow) Van Huerck

Thalassiosira antarctica Comber

Thalassiosira complicata Gersonde

Thalassiosira eccentrica (Ehrenberg) Cleve

Thalassiosira elliptipora (Donahue) Fenner

Thalassiosira fasciculata Harwood et Maruyama

Harwood and Maruyama (1992) plate 15, figs. 5-6

Thalassiosira sp. cf. insigna / inura transitional

Representative illustrations: Harwood and

Maruyama (1992) plate 14, figs. 8-10

Thalassiosira inura Gersonde

Thalassiosira kolbei (Jousé) Gersonde

Thalassiosira lentiginosa (Janisch) Fryxell

Thalassiosira oliverana (O'Meara) Sournia

Thalassiosira striata Harwood et Maruyama

Thalassiosira teres Winter

Representative illustrations: Winter et al. (2012b) figure 5, nos. 14-15; Iwai and Winter (2002) plate 19, figs. 1-6, 8 (as Thalassiosira aff. trifulta group)

Thalassiosira spp.

Thalassiosira torokina Brady

Thalassiosira tumida (Janisch) Hasle

Thalassiosira vulnifica (Gombos) Fenner

Representative illustrations: Mahood and Barron (1997) figs. 25 and 26; Harwood and Maruyama (1992) plate 15, fig. 1; Gombos (1977) plate 4, figs. 1-2 (as Coscinodiscus vulnificus); Fenner (1991) plate 3, fig. 5; Iwai and Winter (2002) plate 15, fig. 1

Thalassiosira webbi Harwood et Maruyama

Thalassiothrix antarctica Schimp ex Karsten

Trichotoxon reinboldii (Van Heurck) Reid et Round

Trinacria spp.

Remarks: likely reworked 
Acknowledgements - The ANDRILL (Antarctic Geologic Drilling) Program is a multinational collaboration between the Antarctic programs of Germany, Italy, New Zealand and the United States. This study is based upon work supported by the National Science Foundation under Cooperative Agreement No. 0342484 through subawards to both CRR and RBD administered by the ANDRILL Science Management Office at the University of Nebraska - Lincoln and issued through Northern Illinois University, as part of the ANDRILL U.S. Science Support Program. The authors gratefully acknowledge the ANDRILL Program for the award of an ANDRILL Graduate Fellowship to CRR in further support of this work. D. Harwood, J. Barron, C. Sjunneskog, D. Winter, and R. Scherer provided valuable discussion and insights on various elements of diatom-based paleoenvironmental reconstruction. C. Bernhardt and B. Landacre provided advice and support in statistical methodologies. S. Starratt generously provided access to an exceptional light microscope and camera system. This manuscript was improved by early comments from J. Barron and M. Robinson, and by the insightful recommendations of M. Konfirst and two anonymous reviewers. Any opinions, findings, and conclusions or recommendations expressed in this material are those of the authors and do not necessarily reflect the views of the National Science Foundation. Any use of trade, product, or firm names is for descriptive purposes only and does not imply endorsement by the U.S. Government.

\section{References}

Abelmann, A., Gersonde, R., Spiess, V., 1990. Pliocene-Pleistocene paleoceanography in the Weddell Sea - siliceous microfossil evidence. Geological history of the polar oceans: Arctic versus Antarctic, pp. 729-759. Abelmann, A., Gersonde, R., Cortese, G., Kuhn, G., Smetacek, V., 2006. Extensive phytoplankton blooms in the Atlantic sector of the glacial SouthernOcean. Paleoceanography 21 (1), PA1013.

Armand, L.K., 1997. The use of diatomtransfer functions in estimating sea-surface temperature and seaice in cores from the southeast Indian Ocean. The Australian National University, Canberra . (392 pp.).

Armand, L.K., 2000. An ocean of ice - advances in estimation of past sea ice in the Southern Ocean. GSA Today 10 (3), 1-7.

Armand, L.K., Leventer, A.R., 2010. Palaeo sea ice distribution and reconstruction derived from the geological records, In: Thomas, D.N., Dieckmann, G.S. (Eds.), Sea Ice, 2nd edition. Wiley-Blackwell, Oxford, pp. 469-530.

Armand, L.K., Crosta, X., Romero, O., Pichon, J.J., 2005. The biogeography of major diatom taxa in Southern Ocean sediments: 1. Sea ice related species. Palaeogeography, Palaeoclimatology, Palaeoecology 223 (1-2), 93-126.

Armbrust, E.V., 2009. The life of diatoms in the world's oceans. Nature 459 (7244), 185-192.

Arrigo, K.R., Robinson, D.H., Dunbar, R.B., Leventer, A.R., Lizotte, M.P., 2003. Physical control of chlorophyll a, POC, and TPN distributions in the pack ice of the Ross Sea, Antarctica. Journal of Geophysical Research 108 (C10, 3316), 14-1-14-23.

Barron, E.J., 1985. Explanations for the Tertiary global cooling trend. Palaeogeography, Palaeoclimatology, Palaeoecology 50, 729-739.

Barron, J.A., 1996a. Diatom constraints on the position of the Antarctic Polar Front in the middle part of the Pliocene. Marine Micropaleontology 27, 195-213.

Barron, J.A., 1996b. Diatom constraints on sea surface temperatures and sea ice distribution during the middle part of the Pliocene. U.S. Geological Survey Open File Report, OF96- 0713 (45 pp.).

Berger, W.H., 2007. Cenozoic cooling, Antarctic nutrient pump, and the evolution of whales. Deep Sea Research Part II: Topical Studies in Oceanography 54 (21-22), 2399-2421.

Bohaty, S.M., Scherer, R.P., Harwood, D.M., 1998. Quaternary diatom biostratigraphy and palaeoenvironments of the CRP-1 Drillcore, Ross Sea, Antarctica. Terra Antartica 5 (3), 431-453.

Brady, H.T., 1981. Late Cenozoic history of Taylor and Wright Valleys and McMurdo Sound inferred from diatoms in Dry ValleyDrilling Project cores. Antarctic Geoscience 1123-1131.

Burckle, L.H., 1984. Diatom distribution and paleoceanographic reconstruction in the Southern Ocean - present and last glacial maximum. Marine Micropaleontology 9 (3), 241-261.

Burckle, L.H., Cirilli, J., 1987. Origin of diatom ooze belt in the Southern Ocean: implications for late Quaternary paleoceanography. Micropaleontology 33 (1), 82-86.

Cermeño, P., Falkowski, P.G., 2009. Controls on diatombiogeography in the Ocean. Science 325 (5947), 1539-1541.

Chow, J.M., 2010. Diatom stratigraphy defining ice sheet groundign chronology, Ross Sea, Antarctica, Ph.D. dissertation, Louisiana State University, Baton Rouge, 248 pp.

Cody, R.D., Levy, R.H., Harwood, D.M., Sadler, P.M., 2008. Thinking outside the zone: high-resolution quantitative diatom biochronology for the Antarctic Neogene. Palaeogeography, Palaeoclimatology, Palaeoecology 260 (1-2), 92-121.

Comiso, J.C., Parkinson, C.L., Gersten, R., Stock, L., 2008. Accelerated decline in the Arctic Sea ice cover. Geophysical Research Letters 35 (1), 6.

Crosta, X., Pichon, J.-J., Labracherie, M., 1997. Distribution of Chaetoceros resting spores in modern peri-Antarctic sediments. Marine Micropaleontology 29 (3-4), 283-299.

Crosta, X., Romero, O., Armand, L.K., Pichon, J.-J., 2005. The biogeography ofmajor diatom taxa in Southern Ocean sediments: 2. Open ocean related species. Palaeogeography, Palaeoclimatology, Palaeoecology 223 (1-2), 66-92.

Crosta, X., Denis, D., Ther, O., 2008. Sea ice seasonality during the Holocene, Adelie Land, East Antarctica. Marine Micropaleontology 66 (3-4), 222-232.

DeConto, R., Pollard, D., Harwood, D., 2007. Sea ice feedback and Cenozoic evolution of Antarctic climate and ice sheets. Paleoceanography 22 (3).

Denis, D., Crosta, X., Zaragosi, S., Romero, O., Martin, B., Mas, V., 2006. Seasonal and subseasonal climate changes recorded in laminated diatom ooze sediments, Adelie Land, East Antarctica. The Holocene 16 (8), 1137-1147.

Dowsett, H.J., 2007. The PRISMpaleoclimate reconstruction and Pliocene sea-surface temperature. In: Williams, M., Haywood, A.M., Gregory, F.J., Schmidt, D.N. (Eds.), Deeptime perspectives on climate change: marrying the signal from computer models and biological proxies. : The Micropalaeontological Society, Special Publications. The Geological Society, London.

Dowsett, H., Barron, J., Poore, R., 1996. Middle Pliocene sea surface temperatures: A global reconstruction. Marine Micropaleontology 27 (1-4), 13-25. Dowsett, H.J., Barron, J.A., Poore, R.Z., Thompson, R.S., 
Cronin, T.M., Ishman, S.E.,Willard, D.A., 1999. Middle Pliocene paleoenvironmental reconstruction: PRISM 2. US Geological Survey Open File Report (99-535), p. 31.

Dowsett, H.J., Robinson, M.M., Foley, K.M., 2009. Pliocene three-dimensional global ocean temperature reconstruction. Climate of the Past Discussions 5, 1901-1928.

Dowsett, H.J., Robinson, M.M., Haywood, A.M., Hill, D.J., Dolan, A.M., Stoll, D.K., Chan, W.-L., AbeOuchi, A., Chandler, M.A., Rosenbloom, N.A., OttoBliesner, B.L., Bragg, F.J., Lunt, D.J., Foley, K.M., Riesselman, C.R., 2012. Assessing confidence in Pliocene sea surface temperatures to evaluate predictive models. Nature Climate Change 2 (5), 365-371.

Dunbar, R.B., Mucciarone, D.A., Long, M.C., Sohst, B., 2006. Hydrographic properties of the Ross Sea Continental Shelf during December, 2005, and January 2006, NBP0601 - CORSACS. Stanford University Ocean Biogeochemistry Group report, 06-04 (42 pp.).

Esper, O., Gersonde, R., Kadagies, N., 2010. Diatom distribution in southeastern Pacific surface sediments and their relationship to modern environmental variables. Palaeogeography, Palaeoclimatology, Palaeoecology 287 (1-4), 1-27.

Falconer, T., Pyne, A., Levy, R., Olney, M., Curren, M., 2007. Operations overview for the ANDRILL McMurdo Ice Shelf Project, Antarctica. Terra Antartica 14 (3), 131-140.

Falkowski, P.G., Oliver, M.J., 2007. Mix and match: how climate selects phytoplankton. Nature Reviews Microbiology 5 (10), 813-819.

Fenner, J.M., 1991. Late Pliocene-Quaternary quantitative diatom stratigraphy in the Atlantic sector of the Southern Ocean. Proceedings of the Ocean Drilling Program,

Scientific Results 114, 97-121.

Flohn, H., 1984. Climate evolution in the Southern hemisphere and the equatorial region during the late Cenozoic. In: Vogel, J.C. (Ed.), Late Cainozoic Paleoclimates of the Southern Hemisphere, pp. 5-20.

Fryxell, G.A., Hasle, G.R., 1980. The marine diatom Thalassiosira Oestrupii: structure, taxonomy and distribution. American Journal of Botany 67 (5), 804-814.

Gersonde, R., 1989. Taxonomy and morphostructure of Late Neogene diatoms from Maud Rise (Antarctic Ocean). Polarforschung 59 (3), 141-171.

Gibbs, M.T., Kump, R.L., 1994. Global chemical erosion during the last glacial maximum and the present: sensitivity to changes in lithology and hydrology. Paleoceanography 9, 529-543.

Gombos, A.M., 1977. Paleogene and Neogene diatoms from the Falkland Plateau and Malvinas Outer Basin: Leg 36, Deep Sea Drilling Project. Initial Reports Deep Sea Drilling Project 36, 575-687.

Gordon, A., 2009. Bottom water formation. In: Steele, J.H., Thorpe, S.A., Turekian, K.K. (Eds.), Ocean Currents: a Derivative of the Encyclopedia of Ocean Sciences. Academic Press, pp. 263-269.

Gradstein, F.M., Ogg, J.G., Smith, A.G. (Eds.), 2005. A Geologic Time Scale 2004. Cambridge University Press, Cambridge (610 pp.).

Grimm, E.C., 1987. CONISS: A FORTRAN 77 program for stratigraphically constrained cluster analysis by the method of incremental sum of squares. Computers \& Geosciences 13 (1), 13-35. Gupta, A.K., Thomas, E., 2003. Initiation of Northern Hemi- sphere glaciation and strengthening of the northeast Indian monsoon: Ocean Drilling Program Site 758, eastern equatorial Indian Ocean. Geology 31 (1), 47-50.

Harwood, D.M., Maruyama, T., 1992. Middle Eocene to Pleistocene diatom biostratigraphy of Southern Ocean sediments from the Kerguelen Plateau, Leg 120. Proceedings of the Ocean Drilling Program, Scientific Results 120, 683-733.

Harwood, D.M., McMinn, A., Quilty, P.G., 2000. Diatom biostratigraphy and age of the Pliocene Sørsdal Formation, Vestfold Hills, East Antarctica. Antarctic Science 12 (4), 443-462.

Hasle, G.R., 1965. Nitzschia and Fragilariopsis species studied in the light and electron microscopes. III. The genus Fragilariopsis. Det Norske Videnskaps-Akademi, 21. Universitetsforlaget, Oslo.

Haywood, A.M., Valdes, P.J., 2004. Modelling Pliocene warmth: contribution of atmosphere, oceans and cryosphere. Earth and Planetary Science Letters 218 (3-4), 363-377.

Haywood, A.M., Smellie, J.L., Ashworth, A.C., Cantrill, D.J., Florindo, F., Hambrey, M.J., Hill, D., Hillenbrand, C.-D., Hunter, S.J., Larter, R.D., Lear, C.H., Passchier, S., van de Wal, R., Fabio, F., Martin, S., 2008. Middle Miocene to Pliocene History of Antarctica and the Southern Ocean. In: Florindo, F., Siegert, M. (Eds.), Antarctic Climate Evolution, Developments in Earth and Environmental Sciences. Elsevier, pp. 401-463.

Haywood, A.M., Chandler, M.A., Valdes, P.J., Salzmann, U., Lunt, D.J., Dowsett, H.J., 2009a. Comparison of mid-Pliocene climate predictions produced by the HadAM3 and GCMAM3 General Circulation Models. Global and Planetary Change 66 (3-4), 208-224.

Haywood, A.M., Dowsett, H.J., Valdes, P.J., Lunt, D.J., Francis, J.E., Sellwood, B.W., 2009b. Introduction. Pliocene climate, processes and problems. Philosophical Transactions of the Royal Society A: Mathematical, Physical and Engineering Sciences 367 (1886), 3-17.

Holm-Hansen, O., Mitchell, B.G., 1991. Spatial and temporal distribution of phytoplankton and primary production in the western Bransfield Strait region. Deep-Sea Research Part A - Oceanographic Research Papers 38 (8-9), 961-980. IPCC, 2007. Cambridge University Press, Cambridge, United Kingdom and New York, NY, USA.

Iwai, M., Winter, D., 2002. Data report: taxonomic notes of Neogene diatoms from the western Antarctic Peninsula: Ocean Drilling Program Leg178. Proceedings of the Ocean Drilling Program, Scientific Results 178, 1-57.

Jansen, E., Overpeck, J.T., Briffa, K.R., Duplessy, J.-C., Joos, F., Masson-Delmotte, V., Olago, D., Otto-Bliesner, B., Peltier, W.R., Rahmstorf, S., Ramesh, R., Rind, D., Solomina, O., Villalba, R., Zhang, R. (Eds.), 2007. Palaeoclimate. Climate Change 2007: The Physical Science Basis. Contribution of Working Group I to the Fourth Assessment Report of the Intergovernmental Panel on Climate Change. Cambridge University Press, Cambridge, United Kingdom and New York, NY, USA.

Johansen, J.R., Fryxell, G.A., 1985. The genus Thalassiosira (Bacillariophyceae): studies on species occurring south of the Antarctic Convergence Zone. Phycologia 24 (2), 155-179.

Kemp, A.E.S., Pike, J., Pearce, R.B., Lange, C.B., 2000. The "Fall dump" - a new perspective on the role of a "shade flora" in the annual cycle of diatom production and export flux. Deep Sea Research Part II: Topi- 
cal Studies in Oceanography 47 (9-11), 2129-2154.

Konfirst, M.A., Scherer, R.P., 2012. Low amplitude obliquity changes during the early Pliocene reflected in diatom fragmentation patterns in the ANDRILL AND-1B core. Marine Micropaleontology 82, 46-52.

Konfirst, M.A., Kuhn, G., Monien, D., Scherer, R.P., 2011. Correlation of Early Pliocene diatomite to low amplitude Milankovitch cycles in the ANDRILL AND-1B drill core. Marine Micropaleontology 80 (3-4), 114-124.

Konfirst, M.A., Kuhn, G., Monien, D., Scherer, R.P., 2012. The influence of siliciclastic input on Chaetoceros abundance in an early Pliocene segment of the ANDRILL AND-1B drill core. Palaeogeography, Palaeoclimatology, Palaeoecology 346-347, 87-94.

Krissek, L., Browne, G., Carter, L., Cowan, E., Dunbar, G., McKay, R., Naish, T., Powell, R., Reed, J., Wilch, T., 2007. Sedimentology and stratigraphy of the AND-1B core, ANDRILL McMurdo Ice Shelf Project, Antarctica. Terra Antartica 14 (3), 185-222.

Lemke, P.E., Trinki, E.W., Hasselman, K., 1980. Stochastic dynamic analysis of polar seaice variability. Journal of Physical Oceanography 97, 2100-2120.

Leventer, A., 1991. Sediment trap diatom assemblages fromthe northern Antarctic Peninsula region. Deep-Sea Research Part A - Oceanographic Research Papers 38 (8-9), 1127-1143.

Leventer, A., Dunbar, R.B., 1996. Factors influencing the distribution of diatoms and other algae in the Ross Sea. Journal of Geophysical Research 101 (C8), 18489-18500.

Leventer, A., Dunbar, R.B., Demaster, D.J., 1993. Diatomevidence for late Holocene climatic events in Granite Harbor, Antarctica. Paleoceanography 8 (3), 373-386.

Leventer, A., Domack, E., Dunbar, R., Pike, J., Stickley, C., Maddison, E., Brachfeld, S., Manley, P., McClennen, C., 2006. Marine sediment record from the East Antarctic margin reveals dynamics of ice sheet recession. GSA Today 16 (12), 4-10.

Ligowski, R., Godlewski, M., Luwokski, A., 1992. Sea ice diatoms and ice edge phytoplankton diatoms at the northern limit of the Weddell Sea pack ice. Polar Biology 5, 9-20.

Lisiecki, L.E., Raymo, M.E., 2005. A Pliocene-Pleistocene stack of 57 globally distributed benthic $\delta 18 \mathrm{O}$ records. Paleoceanography $20 \quad$ (1).

Liu, S., Ye, X.W., Zhang, J., Zhao, Y.F., 2002. Problems with biogenic silica measurement in marginal seas. Marine Geology 192 (4), 383-392.

Mahood, A.D., Barron, J.A., 1997. Comparative ultrastructure of two closely related Thalassiosira species: Thalassiosira vulnifica (Gombos) Fenner and T. fasciculate Harwood et Maruyama. Diatom Research 11 (2), 283-295.

Martin, J.H., 1990. Glacial-interglacial CO2 change: the iron hypothesis. Paleoceanography 5, 1-13.

Martínez-Garcia, A., Rosell-Mele, A., Jaccard, S.L., Geibert, W., Sigman, D.M., Haug, G.H., 2011. Southern Ocean dust-climate coupling over the past four million years. Nature 476 (7360), 312-315.

Marx, F.G., Uhen, M.D., 2010. Climate, critters, and cetaceans: Cenozoic drivers of the evolution of modern whales. Science 327 (5968), 993-996.

Matthews, R.K., Poore, R.Z., 1980. Tertiary $\delta 180$ record and glacio-eustatic sea-level fluctuations. Geology 8, 501-504.

McKay, R., Browne, G., Carter, L., Cowan, E., Dunbar, G., Krissek, L., Naish, T., Powell, R., Reed, J., Talarico, F.,
Wilch, T., 2009. The stratigraphic signature of the late Cenozoic Antarctic ice sheets in the Ross Embayment. Geological Society of America Bulletin 121 (11-12), 1537-1561.

McKay, R., Naish, T., Carter, L., Riesselman, C., Sjunneskog, C., Winter, D., Dunbar, R., Sangiorgi, F., Warren, C., Pagani, M., Schouten, S., Wilmott, V., Levy, R., Powell, R., 2012. Antarctic and Southern Ocean influences on global Late Pliocene cooling. Proceedings of the National Academy of Sciences 109 (17), 6423-6428.

Miller, M.F., Mabin, M.C.G., 1998. Antarctic Neogene landscapes - in the refrigerator or in the deep freeze. GSA Today 8 (4), 1-3. Naafs, B.D.A., Stein, R., Hefter, J., Khélifi, N., De Schepper, S., Haug, G.H., 2010. Late Pliocene changes in the North Atlantic Current. Earth and Planetary Science Letters 298 (3-4), 434-442.

Naish, T.R., Wilson, G.S., 2009. Constraints on the amplitude of Mid-Pliocene (3.6-2.4 Ma) eustatic sea-level fluctuations from the New Zealand shallow-marine sediment record. Philosophical Transactions of the Royal Society A:Mathematical, Physical and Engineering Sciences 367 (1886), 169-187.

Naish, T., Powell, R., Levy, R., 2007a. Background to the ANDRILL McMurdo Ice Shelf Project (Antarctica) and initial science volume. Terra Antartica 14 (3), 121-130.

Naish, T., Powell, R., Levy, R., Florindo, F., Harwood, D., Kuhn, G., Niessen, F., Talarico, F., Wilson, G., 2007b. A record of Antarctic climate and ice sheet history recovered. Eos 88 (50), 557-558.

Naish, T., Powell, R., Levy, R., Wilson, G., Scherer, R., Talarico, F., Krissek, L., Niessen, F., Pompilio, M., Wilson, T., Carter, L., DeConto, R., Huybers, P., McKay, R., Pollard, D., Ross, J., Winter, D., Barrett, P., Browne, G., Cody, R., Cowan, E., Crampton, J., Dunbar, G., Dunbar, N., Florindo, F., Gebhardt, C., Graham, I., Hannah, M., Hansaraj, D., Harwood, D., Helling, D., Henrys, S., Hinnov, L., Kuhn, G., Kyle, P., Laufer, A., Maffioli, P., Magens, D., Mandernack, K., McIntosh, W., Millan, C., Morin, R., Ohneiser, C., Paulsen, T., Persico, D., Raine, I., Reed, J., Riesselman, C., Sagnotti, L., Schmitt, D., Sjunneskog, C., Strong, P., Taviani, M., Vogel, S.,Wilch, T.,Williams, T., 2009. Obliquity- paced PlioceneWest Antarctic ice sheet oscillations. Nature 458 (7236), 322-328.

Pollard, D., DeConto, R.M., 2009. Modelling West Antarctic ice sheet growth and collapse through the past five million years. Nature 458 (7236), 329-U89.

Raphael,M.N., 2003. Impact of observed sea-ice concentration on the Southern Hemisphere extratropical atmospheric circulation in summer. Journal of Geophysical Research 108 (D22), ACL1.1-ACL1.11.

Raymo, M.E., Lisiecki, L.E., Nisancioglu, K.H., 2006. Plio-Pleistocene ice volume, Antarctic climate, and the global $\delta 180$ record. Science 313 (5786), 492-495.

Riesselman, C.R., in press. Fragilariopsis tigris, a new late Pliocene Antarctic continental shelf diatom with biostratigraphic promise. Micropaleontology 58 (4).

Romero, O.E., Armand, L.K., Crosta, X., Pichon, J.J., 2005. The biogeography of major diatom taxa in Southern Ocean surface sediments: 3. Tropical/subtropical species. Palaeogeography, Palaeoclimatology, Palaeoecology 223 (1-2), 49-65.

Röthlisberger, R., Crosta, X., Abram, N.J., Armand, L., Wolff, E.W., 2010. Potential and limitations of marine and ice 
core sea ice proxies: an example from the Indian Ocean sector. Quaternary Science Reviews 29 (1-2), 296-302.

Scherer, R.P., 1991. Quaternary and Tertiary microfossils from beneath Ice Stream B - evidence for a dynamic West Antarctic Ice-Sheet history. Global and Planetary Change 90 (4), 395-412.

Scherer, R.P., Sjunneskog, C.M., Iverson, N.R., Hooyer, T.S., 2004. Assessing subglacial processes from diatom fragmentation patterns. Geology 32 (7), 557-560.

Scherer, R., Hannah, M., Maffioli, P., Persico, D., Sjunneskog, C., Strong, C.P., Taviani, M., Winter, D., 2007. Palaeontologic characterisation and analysis of the AND-1B Core, ANDRILL McMurdo Ice Shelf Project, Antarctica. Terra Antartica 14 (3), 223-254.

Scott, F.J., Thomas, D.P., 2005. Diatoms. In: Scott, F.J., Marchant, H.J. (Eds.), Antarctic Marine Protists. Australian Biological Resources Study and Australian Antarctic Division, Canberra and Hobart, pp. 13-201.

Scott, P., McMinn, A., Hosie, G., 1994. Physical parameters influencing diatom community structure in eastern Antarctic sea ice. Polar Biology 14 (8), 507-517.

Sedwick, P.N., DiTullio, G.R., 1997. Regulation of algal blooms in Antarctic Shelf Waters by the release of iron from melting sea ice. Geophysical Research Letters 24 (20), 2515-2518.

Serreze, M.C., Holland, M.M., Stroeve, J., 2007. Perspectives on the Arctic's shrinking sea-ice cover. Science 315 (5818), 1533-1536.

Sjunneskog, C.,Winter,D., 2012. A diatom record of late Pliocene cooling from the Ross Sea continental shelf, AND-1B, Antarctica. Global and Planetary Change (96-97), 87-96.

Sjunneskog, C., Riesselman, C., Winter, D., Scherer, R., 2012. Fragilariopsis diatom evolution in Pliocene and Pleistocene Antarctic shelf sediments. Micropaleontology $58 \quad$ (3), 273-289.

Stickley, C.E., Pike, J., Leventer, A., Dunbar, R., Domack, E.W., Brachfeld, S., Manley, P., McClennan, C., 2005. Deglacial ocean and climate seasonality in laminated diatom sediments, Mac.Robertson Shelf, Antarctica. Palaeogeography, Palaeoclimatology, Palaeoecology 227 (4), 290-310.

Stockwell, D.A., Hargraves, P.E., 1984. Morphological variability within resting spores of the marine diatom genus Chaetoceros Ehrenberg. Proceedings of the Eighth International Diatom Symposium. Koenigstein, Paris, pp. 81-95.

Strickland, J.D., Parsons, T.R., 1976. Practical handbook of seawater analysis. Fisheries Research Board of Canada Bulletin 167311 pp.

Stroeve, J., Serreze,M., Holland, M., Kay, J., Malanik, J., Barrett, A., 2012. The Arctic's rapidly shrinking sea ice cover: a research synthesis. Climatic Change 110 (3), 1005-1027.

Suto, I., 2006. The explosive diversification of the diatom genus Chaetoceros across the Eocene/Oligocene and Oligocene/Miocene boundaries in the Norwegian Sea. Marine Micropaleontology 58 (4), 259-269.

Sweeney, C., 2003. The annual cycle of surface water $\mathrm{CO} 2$ and $\mathrm{O} 2$ in the Ross Sea: a model for gas exchange on the continental shelves of Antarctica. In: DiTullio, G.R., Dunbar, R.B. (Eds.), Biogeochemistry of the Ross Sea. American Geophysical Union, Antarctic Research Series 78, Washington DC, pp. 295-312.

Tortell, P.D., Payne, C.D., Li, Y.Y., Trimborn, S., Rost, B., Smith, W.O., Riesselman, C., Dunbar, R.B., Sedwick, P., DiTullio, G.R., 2008. CO2 sensitivity of Southern Ocean phytoplankton. Geophysical Research Letters 35 (4). Truesdale, R.S., Kellogg, T.B., 1979. Ross Sea diatoms: modern assemblage distributions and their relationship to ecologic, oceanographic, and sedimentary conditions. Marine Micropaleontology 4 (C), 13-31.

Whitehead, J.M., Bohaty, S.M., 2003. Data report: Quaternary-Pliocene diatom biostratigraphy of ODP Sites 1165 and 1166, Cooperation Sea and Prydz Bay. Proceedings of the Ocean Drilling Program, Scientific Results 188, 1-25.

Whitehead, J.M., McKelvey, B.C., 2001. The stratigraphy of the Pliocene-lower Pleistocene Bardin Bluffs Formation, Amery Oasis, northern Prince Charles Mountains, Antarctica. Antarctic Science 13 (1), 79-86.

Whitehead, J.M., McMinn, A., 2002. Kerguelen Plateau Quaternary-late Pliocene palaeoenvironments: from diatom, silicoflagellate and sedimentological data. Palaeogeography, Palaeoclimatology, Palaeoecology 186 (3-4), 335-368.

Whitehead, J.M., Quilty, P.G., Harwood, D.M., McMinn, A., 2001. Early Pliocene paleoenvironment of the Sørsdal Formation, Vestfold Hills, based on diatom data. Marine Micropaleontology 41 (3-4), 125-152.

Whitehead, J.M., Harwood, D.M., McKelvey, B.C., Hambrey, M.J., McMinn, A., 2004. Diatom biostratigraphy of the Cenozoic glaciomarine Pagodroma Group, northern Prince Charles Mountains, East Antarctica. Australian Journal of Earth Sciences 51 (4), 521-547.

Whitehead, J.M., Wotherspoon, S., Bohaty, S.M., 2005. Minimal Antarctic sea ice during the Pliocene. Geology 33 (2), 137-140.

Wilson, G.S., Levy, R., Browne, G., Cody, R., Dunbar, N., Florindo, F., Henrys, S., Graham, I., McIntosh, W., McKay, R., Naish, T.R., Ohneiser, C., Powell, R., Ross, J., Sagnotti, L., Scherer, R., Sjunneskog, C., Strong, C.P., Taviani, M., Winter, D., 2007. Preliminary integrated chronostratigraphy of the AND-1B Core, ANDRILL McMurdo Ice Shelf Project, Antarctica. Terra Antartica 14 (3), 297-316.

Winter, D.M., Harwood, D.M., 1997. Integrated diatom biostratigraphy of Late Neogene drillholes in Southern Victoria Land and correlation to Southern Ocean records. The Antarctic Region: Geological Evolution and Processes, pp. 985-992.

Winter, D., Sjunneskog, C., Harwood, D., 2010. Early to mid-Pliocene environmentally constrained diatom assemblages from the AND-1B drillcore, McMurdo Sound, Antarctica. Stratigraphy 7 (2-3), 207-227.

Winter, D., Sjunneskog, C., Scherer, R., Maffioli, P., Harwood, D., 2012a. Diatom-based correlation of early to mid-Pliocene drillcores from the southwestern Ross Sea, Antarctica. Global and Planetary Change 96-97, 131-142.

Winter, D., Sjunneskog, C., Scherer, R., Maffioli, P., Riesselman, C., Harwood, D., 2012b. Pliocene-Pleistocene diatom biostratigraphy of nearshore Antarctica from the AND-1B drillcore, McMurdo Sound. Global and Planetary Change 96-97, 59-74.

Zachos, J.C., Quinn, T.M., Salamy, K.A., 1996. Highresolution (104 years) deep-sea foraminiferal stable isotope records of Eocene-Oligocene climate transition. Paleoceanography 11 (3), 251-266.

Zachos, J.C., Pagani, M., Sloan, L., Thomas, E., Billups, K., 2001a. Trends, rhythms, and aberrations in global climate $65 \mathrm{Ma}$ to present. Science 292, 686-693. 
Zachos, J.C., Shackleton, N.J., Revenaugh, J.S., Pälike, H., Flower, B.P., 2001b. Climate forcing across the Oligocene-Miocene boundary. Science 292, 274-278.

Zielinski, U., Gersonde, R., 1997. Diatom distribution in Southern Ocean surface sediments (Atlantic sector): implications for paleoenvironmental reconstructions. Palaeogeography, Palaeoclimatology, Palaeoecology 129 (3-4), 213-250.

Zielinski, U., Gersonde, R., 2002. Plio-Pleistocene diatom biostratigraphy from ODP Leg 177, Atlantic sector of the Southern Ocean. Marine Micropaleontology 45 (3-4), 225-268. 